\title{
Atmospheric dissolved iron deposition to the global oceans: effects of oxalate-promoted Fe dissolution, photochemical redox cycling, and dust mineralogy
}

\author{
M. S. Johnson ${ }^{1, *}$ and N. Meskhidze ${ }^{1}$ \\ ${ }^{1}$ Marine, Earth, and Atmospheric Science, North Carolina State University, Raleigh, NC, USA \\ * now at: NASA Ames Research Center, Moffett Field, CA, USA \\ Correspondence to: N. Meskhidze (nmeskhidze@ncsu.edu)
}

Received: 1 February 2013 - Published in Geosci. Model Dev. Discuss.: 8 March 2013

Revised: 26 June 2013 - Accepted: 1 July 2013 - Published: 7 August 2013

\begin{abstract}
Mineral dust deposition is suggested to be a significant atmospheric supply pathway of bioavailable iron (Fe) to Fe-depleted surface oceans. In this study, mineral dust and dissolved $\mathrm{Fe}\left(\mathrm{Fe}_{\mathrm{d}}\right)$ deposition rates are predicted for March 2009 to February 2010 using the 3-D chemical transport model GEOS-Chem implemented with a comprehensive dust-Fe dissolution scheme. The model simulates $\mathrm{Fe}_{\mathrm{d}}$ production during the atmospheric transport of mineral dust, taking into account inorganic and organic (oxalate)promoted $\mathrm{Fe}$ dissolution processes, photochemical redox cycling between ferric (Fe(III)) and ferrous (Fe(II)) forms of $\mathrm{Fe}$, dissolution of three different Fe-containing minerals (hematite, goethite, and aluminosilicates), and detailed mineralogy of wind-blown dust from the major desert regions. Our calculations suggest that during the year-long simulation $\sim 0.26 \mathrm{Tg}\left(1 \mathrm{Tg}=10^{12} \mathrm{~g}\right)$ of $\mathrm{Fe}_{\mathrm{d}}$ was deposited to global oceanic regions. Compared to simulations only taking into account proton-promoted Fe dissolution, the addition of oxalate and $\mathrm{Fe}(\mathrm{II}) / \mathrm{Fe}(\mathrm{III})$ redox cycling to the dust-Fe mobilization scheme increased total annual model-predicted $\mathrm{Fe}_{\mathrm{d}}$ deposition to global oceanic regions by $\sim 75 \%$. The implementation of $\mathrm{Fe}(\mathrm{II}) / \mathrm{Fe}(\mathrm{III})$ photochemical redox cycling in the model also allows for the distinction between different oxidation states of deposited $\mathrm{Fe}_{\mathrm{d}}$. Our calculations suggest that during the daytime, large fractions of $\mathrm{Fe}_{\mathrm{d}}$ deposited to the global oceans is likely to be in Fe(II) form, while nocturnal fluxes of $\mathrm{Fe}_{\mathrm{d}}$ are largely in $\mathrm{Fe}$ (III) form. Model sensitivity simulations suggest $\mathrm{Fe}_{\mathrm{d}}$ fluxes to the oceans can range from $\sim 50 \%$ reduction to $\sim 150 \%$ increase associated with the uncertainty in Fe-containing minerals commonly found
\end{abstract}

in dust particles. This study indicates that $\mathrm{Fe}_{\mathrm{d}}$ deposition to the oceans is controlled by total dust-Fe mass concentrations, mineralogy, the surface area of dust particles, atmospheric chemical composition, cloud processing, and meteorological parameters and exhibits complex and spatiotemporally variable patterns. Our study suggests that the explicit model representation of individual processes leading to $\mathrm{Fe}_{\mathrm{d}}$ production within mineral dust are needed to improve the understanding of the atmospheric $\mathrm{Fe}$ cycle, and quantify the effect of dust-Fe on ocean biological productivity, carbon cycle, and climate.

\section{Introduction}

Aeolian dust deposition has been suggested to be a critical source of the micronutrient iron (Fe) to $\sim 30 \%$ of the world's oceans, known as high nitrate-low-chlorophyll (HNLC) regions where marine primary productivity can be limited by the supply of Fe (Martin and Fitzwater, 1988; Coale et al., 1996; Boyd et al., 2000). It is further proposed that the supply of Fe may also limit nitrogen fixation, exerting an important control on the primary productivity in vast areas of the global oceans (Falkowski, 1997; Mills et al., 2004). Therefore, the atmospheric supply of Fe to the surface oceans may play a key role in regulating biological productivity, atmospheric carbon dioxide $\left(\mathrm{CO}_{2}\right)$ concentrations, and possibly climate (Martin, 1990; Zhuang et al., 1992; Jickells et al., 2005). 
The majority of $\mathrm{Fe}$ mass found in the atmosphere is contained within mineral dust aerosols emitted from continental sources. Fe in atmospheric mineral dust particles is primarily in the form of Fe-(oxyhydr)oxides, such as hematite $\left(\alpha-\mathrm{Fe}_{2} \mathrm{O}_{3}\right)$ and goethite $(\alpha-\mathrm{FeO}(\mathrm{OH}))$, and as ferric iron $(\mathrm{Fe}(\mathrm{III})$ ) substituted into aluminosilicate minerals (Dedik and Hoffmann, 1992; Hoffmann et al., 1996; Arimoto et al., 2002). In order for Fe, in mineral dust, to be utilized by phytoplankton (i.e., bioavailable Fe), it must be in an aqueous, colloidal, or nanoparticulate form (Raiswell and Canfield, 2012). Additionally, several pathways such as thermal dissolution, mobilization by organic ligands, photo- and bioreduction may also be involved in the acquisition of $\mathrm{Fe}$ by marine organisms, often directly from particulate sources such as mineral dust (Kraemer et al., 2005; Barbeau, 2006; Rubin et al., 2011). As the objective of this study is to estimate the supply of bioavailable lithogenic aerosol Fe to different regions of the global oceans through atmospheric pathways, here we only consider dissolved $\mathrm{Fe}\left(\mathrm{Fe}_{\mathrm{d}}\right)$ production within mineral dust during its atmospheric transport and do not take into account marine processes leading to the formation of bioavailable Fe. The dissolved iron fraction (DIF) $\left(\mathrm{DIF}(\%)=\frac{\mathrm{Fe}_{\mathrm{d}}}{\text { total } \mathrm{Fe}} \times 100\right)$ of Fe-containing minerals commonly found in freshly emitted dust particles are typically small (much less than 1\%); however, in situ measurements suggest increased (up to $5 \%$ ) and spatially variable DIFs downwind from the dust source regions (e.g., Sholkovitz et al., 2012). An important goal in present day climate research is to better understand how physical and chemical processes affect the formation of $\mathrm{Fe}_{\mathrm{d}}$ in mineral dust during atmospheric transport from the source regions to the oceans.

During the atmospheric transport of mineral dust particles Fe can be mobilized through three different mechanisms: proton-promoted, ligand-promoted, and reductive dissolution (Schwertmann, 1991). Fe dissolution in acidic (low $\mathrm{pH})$ environments in deliquesced mineral aerosols or cloud droplets can occur due to high proton concentrations destabilizing Fe-oxygen (Fe-O) bonds in the crystal lattice of $\mathrm{Fe}$-(oxyhydr)oxides and aluminosilicates (Wiederhold et al., 2006; Journet et al., 2008). Past modeling studies that focused on predicting Fe mobilization within mineral dust have primarily concentrated on acidity/pH-dependent dissolution processes (e.g., Meskhidze et al., 2003, 2005; Luo et al., 2005; Mahowald et al., 2009; Solmon et al., 2009; Ito and Feng, 2010; Ito, 2012). The $\mathrm{pH}$ of the aqueous solution surrounding dust aerosols is controlled by the ionic balance between acidic species (e.g., sulfate $\left(\mathrm{SO}_{4}^{2-}\right)$, nitrate $\left(\mathrm{NO}_{3}^{-}\right)$, chloride $\left(\mathrm{Cl}^{-}\right)$anions) and the basic mineral substances contained in dust, i.e., calcite $\left(\mathrm{CaCO}_{3}\right)$. If the concentration of acidic species becomes abundant enough to overcome the alkalinity of mineral dust, the $\mathrm{pH}$ of the aqueous solution surrounding the dust particle will decrease and $\mathrm{Fe}$ can be effectively mobilized from the particle through proton-promoted dissolution processes (Meskhidze et al., 2005). However, due to the large buffering capacity of $\mathrm{CaCO}_{3}$, on average dust particles do not easily become acidic. It has been shown that at $\mathrm{pH}$ values typically found in atmospheric aqueous solutions $(3<\mathrm{pH}<6)$, organic ligand-promoted Fe dissolution is the major mechanism for the production of $\mathrm{Fe}_{\mathrm{d}}$ (Stumm et al., 1985; Dos Santos Afonso et al., 1990; Cornell and Schwertmann, 1996). Out of a number of different Fe(III)chelating ligands, dicarboxylic acids (e.g., oxalate, malonite, glutarite) have been widely studied (Cornell and Schindler, 1987; Duckworth and Martin, 2001). Such organic compounds, and in particular oxalate, are commonly found in atmospheric waters (Kawamura and Ikushima, 1993; Johansen et al., 2000). It has been suggested that the presence of oxalate in ambient aerosols can lead to more than an order of magnitude increase in $\mathrm{Fe}$ dissolution rates (e.g., Pehkonen et al., 1993; Xu and Gao, 2008; Cwiertny et al., 2009; Paris et al., 2011). During ligand-promoted Fe dissolution, organic compounds are thought to form bidentate surface structures (mononuclear - with a single Fe atom on hematite surfaces or binuclear - when two oxygen moieties bridge two $\mathrm{Fe}$ atoms) (Duckworth and Martin, 2001). These ligands, binding as inner-sphere complexes to the surface groups of Fe-oxides, increase dissolution rates due to strong electron donation to surface $\mathrm{Fe}$, weakening the $\mathrm{Fe}-\mathrm{O}$ bond of the mineral lattice and lowering the energy barrier for dissolution (Cornell and Schwertmann, 1996). The third process, known as reductive dissolution, involves an electron transfer to $\mathrm{Fe}$ (III) atoms resulting in $\mathrm{Fe}(\mathrm{II})$ formation. A possible mechanism for the reductive dissolution process, in oxalate containing ambient aerosols, was suggested to start with the photoreduction of $\mathrm{Fe}$ (III)-oxalate complexes (released into solution) to $\mathrm{Fe}$ (II)-oxalate. The $\mathrm{Fe}(\mathrm{II})$-oxalate complex then adsorbs on Fe-(oxyhydr)oxides where it exchanges an electron with a surface $\mathrm{Fe}$ (III) atom. This sunlight-mediated electron exchange increases the rate of dissolution due to both the loss of charge and the increase in size of $\mathrm{Fe}(\mathrm{II})$ (Suter et al., 1991; Cornell and Schwertmann, 1996; Fu et al., 2010). Laboratory studies have demonstrated that in the presence of organic Fe-complexing ligands and UV/visible radiation, higher fractions of $\mathrm{Fe}_{\mathrm{d}}$ can exist in the $\mathrm{Fe}$ (II) form (Zuo and Holgné, 1992; Pehkonen et al., 1993; Cornell and Schwertmann, 1996). It is true that $\mathrm{Fe}(\mathrm{II})$ released from an aerosol particle into seawater upon deposition would be rapidly reoxidized to $\mathrm{Fe}$ (III) with a half-life of a few minutes in warm (tropical, subtropical) seawater to an hour or more in cold polar waters (Millero et al., 1987; Santana-Casiano et al., 2005; Roy et al., 2008). Nevertheless, due to the higher solubility of $\mathrm{Fe}$ (II) compared to $\mathrm{Fe}(\mathrm{III})$, light-induced photochemical cycling of $\mathrm{Fe}$ in the presence of different levels of hydrogen peroxide and organic compounds could strongly influence $\mathrm{Fe}_{\mathrm{d}}$ levels in atmospheric aerosols and cloud droplets (Faust and Zepp, 1993; Chen and Siefert, 2003; Fu et al., 2010). Analysis of rainwater samples also suggested the existence of $\mathrm{Fe}(\mathrm{II})$-complexing ligands that can stabilize wetdeposited $\mathrm{Fe}(\mathrm{II})$ in seawater (Kieber et al., 2005). Since any process which controls $\mathrm{Fe}_{\mathrm{d}}$ concentrations in atmospheric 
waters may influence the amount of $\mathrm{Fe}$ available to phytoplankton, accurate model simulations for photochemical redox cycling of $\mathrm{Fe}$ in atmospheric waters is important for marine biogeochemistry.

In this work $\mathrm{Fe}_{\mathrm{d}}$ deposition rates to the global oceans are calculated using the 3-D global chemical transport model (CTM) GEOS-Chem (v8-01-01) implemented with a prognostic dust-Fe dissolution scheme (hereinafter referred to as GEOS-Chem/ $/ \mathrm{Fe}_{\mathrm{d}}$ ). The proton-promoted dissolution mechanism (Solmon et al., 2009; Johnson et al., 2010, 2011) was updated to simulate $\mathrm{Fe}_{\mathrm{d}}$ production during the atmospheric transport of mineral dust accounting for inorganic and organic (oxalic) acid-promoted $\mathrm{Fe}$ dissolution processes, photochemical redox cycling between $\mathrm{Fe}(\mathrm{III})$ and $\mathrm{Fe}(\mathrm{II})$, dissolution of three different $\mathrm{Fe}$-containing minerals (hematite, goethite, and aluminosilicates), and detailed mineralogy of wind-blown dust from the major desert regions. Model simulations are carried out from March 2009 to February 2010.

\section{Methods}

\subsection{GEOS-Chem}

GEOS-Chem is driven by assimilated meteorological fields from the Goddard Earth Observing System (GEOS) of the NASA Global Modeling Assimilation Office (Bey et al., 2001; Park et al., 2004). During this study the model uses GEOS-5 meteorological fields at a $2^{\circ} \times 2.5^{\circ}$ (latitudelongitude) grid resolution and 47 vertical levels. GEOSChem includes $\mathrm{H}_{2} \mathrm{SO}_{4}-\mathrm{HNO}_{3}-\mathrm{NH}_{3}$ aerosol thermodynamics coupled to an $\mathrm{O}_{3}-\mathrm{NO}_{\mathrm{x}}$-hydrocarbon-aerosol chemical mechanism (Bey et al., 2001; Park et al., 2004). The emissions and chemical transformation of sulfur compounds, carbonaceous aerosols, and sea salt are accounted for and described by Park et al. (2004), Heald et al. (2006), and Alexander et al. (2005). To simulate dust mobilization, GEOS-Chem combines the Dust Entrainment and Deposition (DEAD) scheme (Zender et al., 2003) with the source function used in the Goddard Chemistry Aerosol Radiation and Transport (GOCART) model (Ginoux et al., 2001; Chin et al., 2002). Once mineral dust is mobilized from the surface, the model uses four standard dust bins with diameter boundaries of 0.2 2.0, 2.0-3.6, 3.6-6.0 and 6.0-12.0 $\mu \mathrm{m}$ to simulate global dust transport and deposition (Fairlie et al., 2007). The removal of mineral dust occurs through dry deposition processes such as gravitational settling (Seinfeld and Pandis, 1998) and turbulent dry transfer of particles to the surface (Zhang et al., 2001). Dust removal by wet deposition processes includes both convective updraft scavenging and rainout/washout from large-scale precipitation (Liu et al., 2001). GEOS-Chem emits and deposits, on average, $\sim 1500 \mathrm{Tg} \mathrm{yr}^{-1}$ of mineral dust globally $\left(\sim 1600 \mathrm{Tg} \mathrm{yr}^{-1}\right.$ was predicted during the simulated time period of this study). This modelpredicted flux is consistent with the average global dust deposition value of $\sim 1900 \mathrm{Tg} \mathrm{yr}^{-1}$ (ranging between $\sim 700$ to $4400 \mathrm{Tg} \mathrm{yr}^{-1}$ ) determined from all models used in the AEROCOM phase 1 project (Huneeus et al., 2011).

The prognostic proton-promoted dissolution module (Meskhidze et al., 2005; Solmon et al., 2009) prescribes a globally uniform mineralogical composition of windblown dust and uses aqueous phase equilibrium and dissolution/precipitation reactions for the following minerals contained in dust: calcite, albite, microcline, illite, smectite, gypsum, and hematite (Meskhidze et al., 2005). The dissolution/precipitation of each mineral is explicitly estimated based on solution $\mathrm{pH}$, temperature, dust mineralogy, and the specific surface area of the individual minerals. An initial $\mathrm{Fe}$ solubility of $0.45 \%$ (for the most reactive and poorly crystalline pool of $\mathrm{Fe}$ in desert top soils) is prescribed based on the synthesis of data from the Saharan and Sahel regions of northern Africa (Shi et al., 2012). GEOS-Chem (implemented with the Fe-dissolution mechanism) predicted fluxes of mineral dust and $\mathrm{Fe}_{\mathrm{d}}$ to the surface oceans which have been shown to be in reasonable agreement with available observational/remotely sensed data and past modeling studies (Solmon et al., 2009; Johnson et al., 2010, 2011, 2012).

\subsection{Model developments}

\subsubsection{Dust mineralogical composition}

The mineralogical composition of dust particles is one of the key factors influencing $\mathrm{Fe}$ mobilization during atmospheric transport (Spokes et al., 1994; Sedwick et al., 2007; Journet et al., 2008). In the recent study by Nickovic et al. (2012) it was shown that top-soil/dust mineralogy is spatially heterogeneous and using a globally constant mass fraction for individual minerals may cause inaccuracies in the prediction of the impact of mineral dust on marine biogeochemical processes. Therefore, to account for the spatial heterogeneity in the mineralogy of the atmospherically transportable fraction of top soils, the global dust mineralogy database of Nickovic et al. (2012) was implemented in the model. The dataset was re-gridded from the original $30 \mathrm{~s}$ resolution (approximately $1 \mathrm{~km}$ ) to the $2^{\circ} \times 2.5^{\circ}$ grid resolution used by GEOS-Chem $/ \mathrm{Fe}_{\mathrm{d}}$. The dataset contains percent mass fractions of the following minerals: quartz, illite, kaolinite, smectite, feldspar, calcite, hematite, gypsum, and phosphorus. The mass fraction of $\mathrm{Fe}$ in the mineral database is in a range of 2 $3.6 \%$ with significant geographic variability (Nickovic et al., 2012, 2013). As the fractional contribution of Fe to different minerals (such as silicates (kaolinite, illite, smectite, chlorite) and (oxyhydr)oxides (ferrihydrite, lepidocrocite, goethite, hematite, magnetite)) involved in the biogeochemical cycling of Fe can vary substantially (Nickovic et al., 2013), the Fe content of mineral dust in GEOS-Chem $/ \mathrm{Fe}_{\mathrm{d}}$ was set to a widely accepted value of $3.5 \%$ (e.g., Taylor and McLennan, 1985; Duce and Tindale, 1991). Separate model simulations were carried out using three different minerals (hematite - 
Table 1. Tracers implemented into GEOS-Chem/Fe $\mathrm{d}$ and chemical forms allowed for each species.

\begin{tabular}{ll}
\hline Tracer Symbol & Chemical Forms Allowed for Species \\
\hline $\mathrm{Fe}(\mathrm{III})$ & {$\left[\mathrm{Fe}^{3+}\right]_{\mathrm{aq}},\left[\mathrm{Fe}(\mathrm{OH})^{2+}\right]_{\mathrm{aq}},\left[\mathrm{Fe}(\mathrm{OH})_{2}^{+}\right]_{\mathrm{aq}},\left[\mathrm{Fe}\left(\mathrm{SO}_{4}\right)^{+}\right]_{\mathrm{aq}},\left[\mathrm{FeCl}^{2+}\right]_{\mathrm{aq}},\left[\mathrm{Fe}(\mathrm{OH})_{3}\right]_{\mathrm{s}}$} \\
$\mathrm{Fe}(\mathrm{II})$ & {$\left[\mathrm{Fe}^{2+}\right]_{\mathrm{aq}}$} \\
$\mathrm{FeO}^{2+}$ & {$\left[\mathrm{FeO} \mathrm{O}_{\mathrm{aq}}\right.$} \\
$\mathrm{Fe}(\mathrm{III})$-oxalate & {$\left[\mathrm{Fe}\left(\mathrm{C}_{2} \mathrm{O}_{4}\right)^{+}\right]_{\mathrm{aq}},\left[\mathrm{Fe}\left(\mathrm{C}_{2} \mathrm{O}_{4}\right)_{2}^{-}\right]_{\mathrm{aq}},\left[\mathrm{Fe}\left(\mathrm{C}_{2} \mathrm{O}_{4}\right)_{3}^{3-}\right]_{\mathrm{aq}}$} \\
$\mathrm{Fe}(\mathrm{II})$-oxalate1 & {$\left[\mathrm{Fe}\left(\mathrm{C}_{2} \mathrm{O}_{4}\right)\right]_{\mathrm{aq}}$} \\
$\mathrm{Fe}(\mathrm{II})-$-oxalate2 & {$\left[\mathrm{Fe}\left(\mathrm{C}_{2} \mathrm{O}_{4}\right)_{2}^{2-}\right]_{\mathrm{aq}}$} \\
Oxalate & {$\left[\mathrm{H}_{2}\left(\mathrm{C}_{2} \mathrm{O}_{4}\right)\right]_{\mathrm{aq}},\left[\mathrm{H}\left(\mathrm{C}_{2} \mathrm{O}_{4}\right)^{-}\right]_{\mathrm{aq}},\left[\mathrm{C}_{2} \mathrm{O}_{4}^{2-}\right]_{\mathrm{aq}}$} \\
\hline
\end{tabular}

for the baseline simulations, and goethite and illite for sensitivity calculations) as the main Fe containing mineral. Such treatment allowed us to assess the importance of oxalatepromoted dissolution and the photochemical redox cycling of $\mathrm{Fe}$ implemented in GEOS-Chem/ $/ \mathrm{Fe}_{\mathrm{d}}$ by comparing results of the current study with the proton-promoted dissolution of Meskhidze et al. (2005), while still giving an estimate for a range of uncertainty associated with the incomplete characterization of Fe-mineralogy in desert soils (see Sect. 3.2.5 for sensitivity calculations).

In order to determine the influence of individual major global dust source regions on atmospheric fluxes of $\mathrm{Fe}_{\mathrm{d}}$, following Prospero et al. (2002) GEOS-Chem/ $/ \mathrm{Fe}_{\mathrm{d}}$ was set up to treat seven (North Africa, South Africa, North America, Asia, Australia, the Middle East, and South America) dust source regions separately. In the model each source region is assigned separate tracers to represent mineralogy as well as chemistry. Such a treatment allows dust from each of the seven major source regions to be independently emitted, transported, chemically transformed, and removed from the atmosphere. This model development increased the number of additional tracers in GEOS-Chem/ $/ \mathrm{Fe}_{\mathrm{d}}$ (by a factor of 7), causing a considerable increase in computational cost. Therefore, the selection of different dust source regions is available as a user-defined option in the updated GEOS$\mathrm{Chem} / \mathrm{Fe}_{\mathrm{d}}$ model.

\subsubsection{Model-predicted oxalate concentrations}

To simulate organic ligand-promoted Fe dissolution, a new tracer - oxalate - was implemented into GEOS-Chem $/ \mathrm{Fe}_{\mathrm{d}}$ (see Table 1). This organic compound was chosen because of its high affinity to complex with Fe within mineral dust (Cornell and Schindler, 1987) and the fact that oxalate has been shown to be one of the most abundant organic constituents detected in tropospheric aerosols (Kawamura and Ikushima, 1993; Kawamura et al., 2005; Yu et al., 2005). Oxalate has been suggested to have both anthropogenic and natural sources of its precursor gases (Fu et al., 2008; Myriokefalitakis et al., 2008; Sinreich et al., 2010; Volkamer et al., 2010; Rinaldi et al., 2011). The in-cloud oxidation of organic compounds such as glyoxylic acid, glycolic acid, glycolaldehyde, glyoxal, and methylglyoxal are suggested to be the dominant precursors of oxalate (Myriokefalitakis et al., 2011) with additional sources from aromatic hydrocarbons, cyclic olefins, and aldehydes in highly polluted regions (Kleindienst et al., 1999; Yu et al., 2005). The explicit calculations of oxalate formation, as in Myriokefalitakis et al. (2011), consider a complex system of aqueous and gas phase reactions and is outside the scope of the current study. To estimate oxalate concentrations $\left(\left[\mathrm{C}_{2} \mathrm{O}_{4}^{2-}\right]\right.$ in $\mathrm{nmol} \mathrm{m}^{-3}$ ) in GEOS-Chem/ $/ \mathrm{Fe}_{\mathrm{d}}$ we apply the method proposed by $\mathrm{Yu}$ et al. (2005), in which oxalate is calculated using modelpredicted sulfate concentrations $\left(\left[\mathrm{SO}_{4}^{2-}\right]\right.$ in $\left.\mathrm{nmol} \mathrm{m}^{-3}\right)$ :

$\left[\mathrm{C}_{2} \mathrm{O}_{4}^{2-}\right]=0.05 \cdot\left[\mathrm{SO}_{4}^{2-}\right]-0.273$.

The linear fit shown in Eq. (1) was derived using aircraft and ground-based measurements of oxalate and sulfate concentrations collected during the Aerosol Characterization Experiment (ACE)-Asia measurement campaign (Yu et al., 2005). Measurements of oxalate and sulfate in aerosol and cloud water from various urban, remote, and coastal regions in Asia also demonstrate high spatial and temporal correlation $\left(R^{2}=0.49-0.93\right)$ (Yu et al., 2005) and comparable size distributions (Furukawa and Takahashi, 2011). Such a strong relationship was suggested to be due to the similar locations of emitted precursor species and in-cloud formation pathways (Yu et al., 2005; Myriokefalitakis et al., 2011). Over the North Atlantic Ocean variable correlation values between non-sea salt $\mathrm{SO}_{4}^{2-}$ and oxalate were reported from the cruise measurements of Chen and Siefert (2004). The linear correlation coefficients ranged between 0.70 to 0.96 and 0.26 to 0.68 for winter and summer seasons, respectively (Chen and Siefert, 2004), suggesting that oceanic dimethyl sulfide (DMS) $\left(\mathrm{SO}_{4}^{2-}\right.$ precursor gas) emissions may introduce some inaccuracies in our model-predicted oxalate concentrations. Upon the evaporation of cloud droplets and aerosol water, both oxalate and sulfate tend to remain in the particulate phase. To avoid the effect of oxalate not associated with mineral dust, the amount of oxalate considered in organic ligand-promoted $\mathrm{Fe}$ dissolution is calculated based on dust-sulfate concentrations predicted by GEOS$\mathrm{Chem} / \mathrm{Fe}_{\mathrm{d}}$. Model-predicted dust-sulfate concentrations are 
primarily driven by the uptake of sulfur dioxide $\left(\mathrm{SO}_{2}\right)$ and sulfuric acid $\left(\mathrm{H}_{2} \mathrm{SO}_{4}\right)$ from the gas and aqueous phase (incloud sulfate formation).

\subsubsection{Mineral dissolution kinetics}

In this work oxalate-promoted dissolution of three $\mathrm{Fe}$ containing minerals (hematite, goethite, and illite) was added to GEOS-Chem $/ \mathrm{Fe}_{\mathrm{d}}$. Illite was chosen as a proxy for all Fe-containing aluminosilicate minerals. The temperaturedependent dissolution rate constant $K_{i}^{r}\left(\mathrm{~mol} \mathrm{~m}^{-2} \mathrm{~s}^{-1}\right)$ for the Fe-containing mineral " $i$ " in the presence of oxalate is modeled as the sum of proton-promoted and ligand-promoted dissolution rates:

$K_{i}^{r}=\mathrm{Kp}_{i}+\mathrm{Kl}_{i}$

where $\mathrm{Kp}_{i}$ and $\mathrm{Kl}_{i}$ are the proton-promoted and the oxalate-promoted mineral dissolution rate constants, respectively. The $\mathrm{Kp}_{i}$ values for hematite and illite dissolution rates are calculated from the temperature-dependent equations in Table 8 of Meskhidze et al. (2005) and $\mathrm{Kp}_{i}$, the proton-promoted dissolution rate constant for goethite $\left(\mathrm{mol} \mathrm{m}^{-2} \mathrm{~s}^{-1}\right)$, is derived from Cornell et al. (1976) as:

$\mathrm{Kp}_{i}=1.4 \times 10^{-11} \cdot \exp \left[1.1 \times 10^{4} \cdot\left(\frac{1}{298}-\frac{1}{T}\right)\right]$.

The $K_{i}^{r}$ for each individual mineral is then applied to Eq. (24) in Meskhidze et al. (2005) in order to calculate the concentration of mineral $\mathrm{Fe}$ dissolved per time step in the model. The empirical parameter $(m)$, specific surface area of the mineral $(A)$, weight fraction of the mineral in dust $(W)$, and equilibrium constants $\left(K_{\text {eq }}\right)$ used in the proton-promoted dissolution of hematite and illite are listed in Meskhidze et al. (2005). For goethite we use the following values: $m=0.5$, $A=38 \mathrm{~m}^{2} \mathrm{~g}^{-1}, W=5.7 \%$, and $K_{\text {eq }}=2.3 \mathrm{~mol}^{2} \mathrm{~kg}^{-2}$ (Cornell et al., 1976; Cheah et al., 2003). Following the dissolution/precipitation method of Meskhidze et al. (2005), at every time step in the model, rate constants for mineral dissolution/precipitation are derived based on $\mathrm{Fe}_{\mathrm{d}}$, dissolved chemical species, solution $\mathrm{pH}$, temperature, and ionic strength. For any particular mineral (i.e., hematite, goethite, or illite), if the solution remains undersaturated with respect to $\mathrm{Fe}(\mathrm{III})$, mineral dissolution proceeds. However, when the solution becomes super-saturated with respect to Fe(III), mineral dissolution stops and amorphous $\mathrm{Fe}(\mathrm{OH})_{3}(\mathrm{~s})$ precipitates. For all the simulations conducted during this study the solution remained undersaturated with respect to $\mathrm{Fe}(\mathrm{II})$.

The values for $\mathrm{Kl}_{\mathrm{i}}$ for the three different minerals (hematite, goethite, and illite) are taken from Paris et al. (2011). The study by Paris et al. (2011) was selected because it uses oxalate concentrations typically observed in atmospheric aerosols, several orders of magnitude lower compared to many $\mathrm{Fe}$-(oxyhydr)oxide dissolution experiments (e.g., Cornell and Schindler, 1987; Xu and Gao, 2008). The
Table 2. Coefficients $a_{i}\left(\mathrm{~mol} \mathrm{Fe} \mathrm{m}^{-2} \mathrm{~s}^{-1} \mathrm{uM}^{-1} \mathrm{C}_{2} \mathrm{O}_{4}^{2-}\right)$ and $b_{i}$ $\left(\mathrm{mol} \mathrm{Fe} \mathrm{m}^{-2} \mathrm{~s}^{-1}\right.$ ) for oxalate-promoted $\mathrm{Fe}$ dissolution rates of individual Fe-containing minerals.

\begin{tabular}{lccc}
\hline Fe-containing mineral & $a_{i}$ & $b_{i}$ & $R^{2}$ \\
\hline Hematite & $3.0 \times 10^{-12}$ & $-2.0 \times 10^{-12}$ & 0.997 \\
Goethite & $1.0 \times 10^{-11}$ & $7.0 \times 10^{-13}$ & 0.987 \\
Illite & $3.0 \times 10^{-10}$ & $6.0 \times 10^{-11}$ & 0.999 \\
\hline
\end{tabular}

artificial laboratory light used in the Paris et al. (2011) study does not allow UV-light emissions and therefore may lead to a factor of 2 to 3 underestimation of $\mathrm{Fe}$ dissolution rates (e.g., Waite et al., 1986). However, Paris et al. (2011) emphasized that for their experimental conditions, the lightinduced reductive dissolution was not the principal process explaining the increase in $\mathrm{Fe}$ solubility. For acidic solutions $(\mathrm{pH}=4.7)$ containing various concentrations of oxalate, Paris et al. (2011) show a positive linear correlation between $\mathrm{Fe}_{\mathrm{d}}$ and oxalate concentrations for all of the minerals considered. Using this data one can then calculate (after subtracting out the amount of $\mathrm{Fe}_{\mathrm{d}}$ produced in the absence of oxalate) oxalate-promoted mineral dissolution rates for different Fe-containing minerals " $i$ " as $\mathrm{Kl}_{i}=a_{i}[x]+b_{i}$. To calculate these $\mathrm{Kl}_{i}$ rates we applied the total mineral mass $(15 \mathrm{mg})$, $\mathrm{Fe}$ mass percentage of each mineral $(3.38 \%, 57.48 \%$, and $62.87 \%$ for illite, hematite, and goethite, respectively) and the individual mineral specific surface areas $\left(9,1,33 \mathrm{~m}^{2} \mathrm{~g}^{-1}\right.$ for hematite, goethite, and illite, respectively) used in each dissolution experiment of Paris et al. (2011). Coefficients $a_{i}$ and $b_{i}$ (with corresponding $R^{2}$ values) for the linear best fit to the Paris et al. (2011) data are given in Table 2, and $[x]$ represents the aqueous concentration of oxalate $(\mu \mathrm{M})$.

The proton- and oxalate-promoted dissolution rate constants of the three Fe-containing minerals considered in GEOS-Chem $/ \mathrm{Fe}_{\mathrm{d}}$ are shown in Fig. 1. Calculations suggest that out of three Fe-containing minerals illite has the fastest dissolution rate followed by hematite and goethite. Figure 1 shows that at very low $\mathrm{pH}$ values oxalate concentrations have a minor effect on total dissolution rates for all three minerals. As suggested before, for highly acidic conditions the amount of $\mathrm{Fe}_{\mathrm{d}}$ produced in ambient aerosols should mainly be determined by proton-promoted dissolution. On the contrary, for higher $\mathrm{pH}$ values $(\mathrm{pH}>3)$ that are more typical for atmospheric waters, ignoring oxalate-promoted dissolution may lead to the considerable underestimation of $\mathrm{Fe}_{\mathrm{d}}$ production for all three Fe-containing minerals (see Fig. 1). Overall, the rates for oxalate-promoted dissolution shown in Fig. 1 are consistent with past literature (e.g., Sidhu et al., 1981; Schwertmann, 1991; Duckworth and Martin, 2001; Samson and Eggleston, 2002; Journet et al., 2008). In Sect. 3.2.4 sensitivity calculations are presented to illustrate the influence of oxalate on $\mathrm{Fe}_{\mathrm{d}}$ fluxes to the global oceans. 


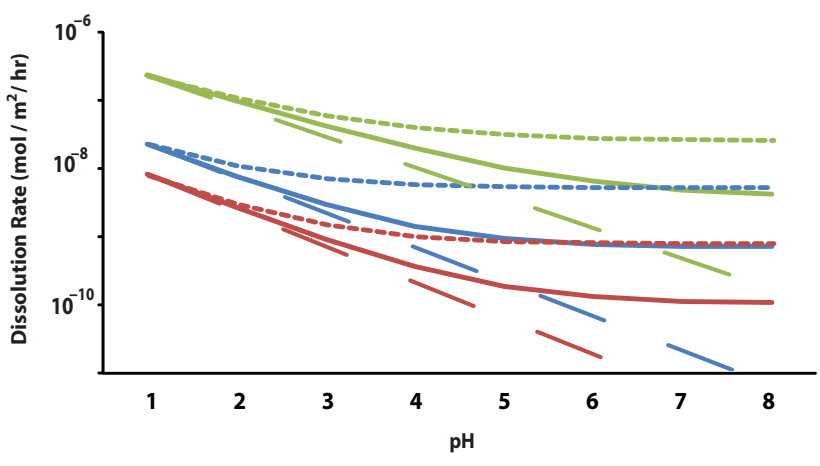

Fig. 1. Dissolution rates $\left(\mathrm{mol} \mathrm{m}^{-2} \mathrm{~h}^{-1}\right)$ for hematite (blue), goethite (red), and illite (green) in atmospheric waters containing oxalate concentrations of $0 \mu \mathrm{M}$ (long-dashed lines), $1 \mu \mathrm{M}$ (solid lines) and $8 \mu \mathrm{M}$ (short-dashed lines) at $298 \mathrm{~K}$.

\subsubsection{Kinetic modeling of photochemical/chemical reactions of $\mathrm{Fe}$ in the presence of oxalate}

Past studies have shown that photochemical reactions of $\mathrm{Fe}$ (III)-oxalate complexes in atmospheric waters can be an important source of Fe(II) (Faust and Zepp, 1993; Siefert et al., 1998; Balmer and Sulzberger, 1999). Photolysis of $\mathrm{Fe}$ (III)-oxalate complexes may also lead to the reduction of oxygen and formation of superoxide and its conjugate acid, hydroperoxide radical $\left(\mathrm{HO}_{2}^{-} / \mathrm{O}_{2}^{--}\right)$, which in turn form hydrogen peroxide $\left(\mathrm{H}_{2} \mathrm{O}_{2}\right)$ (Zuo and Holgné, 1992). Recent studies further suggest that $\mathrm{Fe}(\mathrm{II}) / \mathrm{Fe}$ (III) cycling in aqueous aerosols and cloud droplets can lead to the production of $\mathrm{H}_{2} \mathrm{O}$ (Mao et al., 2013). Since $\mathrm{Fe}_{\mathrm{d}}$ and oxalic acid are ubiquitous pollutants in cloud-, fog-, and rainwater, photochemi$\mathrm{cal} / \mathrm{chemical}$ redox cycling of oxalate-complexed $\mathrm{Fe}$ species could have an important effect on tropospheric $\mathrm{OH}, \mathrm{H}_{2} \mathrm{O}_{2}$, ozone, and other species.

The standard GEOS-Chem tropospheric chemical mechanism consists of over 100 species and 300 reactions integrated using the stiff ordinary first-order differential equation solver Sparse Matrix Vectorized GEAR II (SMVGEAR II) (Jacobson and Turco, 1994; Jacobson, 1995, 1998). The methods used in SMVGEAR II allow the solver to resolve equations quickly and accurately in global 3-D models. During this study, in order to simulate the photochemi$\mathrm{cal} /$ chemical cycle of $\mathrm{Fe}$ (III) and $\mathrm{Fe}$ (II) complexes, oxalate, $\mathrm{H}_{2} \mathrm{O}_{2}$, and radical species $\mathrm{OH}^{-}, \mathrm{HO}_{2}, \mathrm{O}_{2}^{-}$, additional kinetic, photochemical, and aqueous-phase equilibrium reactions listed in Tables 3 and 4 (apart from those described in Meskhidze et al., 2005) were added into SMVGEAR II. Aqueous concentrations of oxidant species were calculated using temperature-dependent Henry's Law. To account for species that do not achieve equilibrium due to mass transfer kinetic limitations between phases we calculate the transfer coefficient following the methods of Myriokefalitakis et al. (2011). The GEOS-Chem model calculates photolysis frequencies using the Fast-J radiative transfer algorithm of Wild et al. (2000), with a seven-wavelength quadrature scheme that calculates photolysis rates throughout the troposphere in the presence of an arbitrary mix of cloud and aerosol layers (Olsen et al., 1997; Wild et al., 2000). Fespecies absorption cross-sections used in photolysis calculations are listed in Table S2. In order to simulate the diurnal variations of photochemical processes, photolysis calculations are performed every hour in the model.

ISORROPIA is an aerosol thermodynamics module used in GEOS-Chem to calculate the equilibrium solid-, aqueousand gas-phase concentrations of the sodium - ammonium - chloride - sulfate - nitrate - liquid-water content system of an internally mixed aerosol (Nenes et al., 1998). Previously, ISORROPIA was modified to include reactions involving gas-phase $\mathrm{CO}_{2}$, aqueous-phase carbonates, and $\mathrm{Fe}$ species (Meskhidze et al., 2005). This modified version of ISORROPIA is applied within GEOS-Chem/ $\mathrm{Fe}_{\mathrm{d}}$. Multicomponent activity coefficients for the major inorganic species were determined using the methods of Bromley (1973). Binary activity coefficients were calculated for each new ion pair using the formulation of Kusik and Meissner (1978) with the q-parameters for each relevant salt listed in Table 9 of Meskhidze et al. (2005). Ionic strength and $\mathrm{pH}$ of the solution are calculated using the modified form of ISORROPIA. Activity coefficients for the following ions $\mathrm{C}_{2} \mathrm{O}_{4}^{2-}, \mathrm{C}_{2} \mathrm{O}_{4}^{-}, \mathrm{FeO}^{2+}, \mathrm{O}_{2}^{-\cdot}$ have been neglected. To consider a potential salting out effect for electrically neutral species $\left(\mathrm{H}_{2} \mathrm{O}_{2}, \mathrm{HO}_{2}, \mathrm{OH}, \mathrm{O}_{3}, \mathrm{O}_{2}\right)$ activity coefficients were calculated as $10^{0.1 \cdot I}$ (Fischer and Peters, 1970), where $I$ stands for the ionic strength of the solution. Additionally, the reactions listed in Tables 3 and 4 are calculated for both aerosol solution and cloud water environments. Aerosol liquid water content is calculated by the thermodynamic module ISORROPIA. When dust aerosols are predicted to be within a cloud, the liquid water content is set to the temperaturedependent cloud water concentration predicted by GEOSChem.

In addition to $\mathrm{Fe}$, oxalate can readily chelate divalent cations such as calcium $\left(\mathrm{Ca}^{2+}\right)$, which is commonly enriched in mineral dust, forming mostly insoluble complexes (e.g., Sullivan et al., 2009). Technically, the formation of these metal-organic ligand complexes may lower the oxalate concentrations available for adsorption onto mineral$\mathrm{Fe}$. However, the reactions of $\mathrm{Ca}^{2+}$ with oxalate have not been included in Table 3 or 4 because recent studies of sizefractionated aerosol samples collected in Tsukuba (a city approximately $60 \mathrm{~km}$ northeast of Tokyo) showed that on average only 2 to $10 \%$ of oxalate is associated with $\mathrm{Ca}^{2+}$ ions (Furukawa and Takahashi, 2011).

Table S1 shows that the primary sources of Fe(II) production are the photochemical reduction of ferric hydroxide, $\mathrm{Fe}(\mathrm{OH})^{2+}$ and $\mathrm{Fe}(\mathrm{III})$-oxalate species and reactions of $\mathrm{Fe}(\mathrm{III})$-hydroxy species with $\mathrm{HO}_{2} / \mathrm{O}_{2}^{-}$radicals. The primary destruction pathways of $\mathrm{Fe}(\mathrm{II})$ (cycling back to $\mathrm{Fe}(\mathrm{III})$ ) 
Table 3. Kinetic and photochemical reactions implemented into SMVGEAR II.

\begin{tabular}{|c|c|c|c|}
\hline & Kinetic Equations & Reaction Rates $\mathrm{M}^{-n} \mathrm{~s}^{-1}$ & Source \\
\hline \multicolumn{4}{|c|}{ Photolysis of Fe(III) species } \\
\hline $\mathrm{J} 1$ & $\mathrm{Fe}(\mathrm{OH})^{2+}+\mathrm{hv} \rightarrow \mathrm{Fe}^{2+}+\mathrm{OH}^{-}$ & $4.51 \times 10^{-3}$ & Benkelberg and Warneck (1995) \\
\hline $\mathrm{J} 2$ & $\mathrm{Fe}\left(\mathrm{C}_{2} \mathrm{O}_{4}\right)_{2}^{-}+\mathrm{hv} \rightarrow \mathrm{Fe}^{2+}+\mathrm{C}_{2} \mathrm{O}_{4}^{2-}+\mathrm{C}_{2} \mathrm{O}_{4}^{-\cdot}$ & $2.47 \times 10^{-2}$ & Faust and Zepp (1993) \\
\hline $\mathrm{J} 3$ & $\mathrm{Fe}\left(\mathrm{C}_{2} \mathrm{O}_{4}\right)_{3}^{3-}+\mathrm{hv} \rightarrow \mathrm{Fe}^{2+}+2 \mathrm{C}_{2} \mathrm{O}_{4}^{2-}+\mathrm{C}_{2} \mathrm{O}_{4}^{-}$ & $1.55 \times 10^{-2}$ & Faust and Zepp (1993) \\
\hline \multicolumn{4}{|c|}{ Fenton reactions } \\
\hline K1 & $\mathrm{Fe}^{2+}+\mathrm{H}_{2} \mathrm{O}_{2} \rightarrow \mathrm{Fe}^{3+}+\mathrm{OH}^{\cdot}+\mathrm{OH}^{-}$ & $5.24 \times 10^{1}$ & Kremer (2003) \\
\hline $\mathrm{K} 2$ & $\mathrm{Fe}\left(\mathrm{C}_{2} \mathrm{O}_{4}\right)+\mathrm{H}_{2} \mathrm{O}_{2} \rightarrow \mathrm{Fe}\left(\mathrm{C}_{2} \mathrm{O}_{4}\right)^{+}+\mathrm{OH}^{-}+\mathrm{OH}^{-}$ & $5.24 \times 10^{4}$ & Sedlak and Hoigné (1993) \\
\hline \multicolumn{4}{|c|}{ Fe reduction and oxidation } \\
\hline $\mathrm{K} 3$ & $\mathrm{Fe}^{2+}+\mathrm{O}_{2}^{-\cdot}+2 \mathrm{H}^{+} \rightarrow \mathrm{Fe}^{3+}+\mathrm{H}_{2} \mathrm{O}_{2}$ & $1.0 \times 10^{7}$ & Rush and Bielski (1985) \\
\hline K4 & $\mathrm{Fe}^{2+}+\mathrm{HO}_{2}+\mathrm{H}^{+} \rightarrow \mathrm{Fe}^{3+}+\mathrm{H}_{2} \mathrm{O}_{2}$ & $1.2 \times 10^{6}$ & Rush and Bielski (1985) \\
\hline K5 & $\mathrm{Fe}^{2+}+\mathrm{NO}_{3} \rightarrow \mathrm{Fe}^{3+}+\mathrm{NO}_{3}^{-}$ & $8.0 \times 10^{6}$ & Pikaev et al. (1974) \\
\hline K6 & $\mathrm{Fe}^{2+}+\mathrm{NO}_{2}+\mathrm{H}^{+} \rightarrow \mathrm{Fe}^{3+}+\mathrm{HNO}_{2}$ & $3.1 \times 10^{4}$ & Epstein et al. (1982) \\
\hline K7 & $\mathrm{Fe}(\mathrm{OH})^{2+}+\mathrm{O}_{2}^{-\cdot} \rightarrow \mathrm{Fe}^{2+}+\mathrm{O}_{2}+\mathrm{OH}^{-}$ & $1.5 \times 10^{8}$ & Rush and Bielski (1985) \\
\hline K8 & $\mathrm{Fe}(\mathrm{OH})^{2+}+\mathrm{HO}_{2} \rightarrow \mathrm{Fe}^{2+}+\mathrm{O}_{2}+\mathrm{H}_{2} \mathrm{O}$ & $1.3 \times 10^{5}$ & Ziajka et al. (1994) \\
\hline K9 & $\mathrm{Fe}^{2+}+\mathrm{O}_{3} \rightarrow \mathrm{FeO}^{2+}+\mathrm{O}_{2}$ & $8.2 \times 10^{5}$ & Logager et al. (1992) \\
\hline K10 & $\mathrm{FeO}^{2+}+\mathrm{H}_{2} \mathrm{O} \rightarrow \mathrm{Fe}^{3+}+\mathrm{OH}^{-}+\mathrm{OH}^{-}$ & $1.3 \times 10^{-2}$ & Jacobsen et al. (1998) \\
\hline K11 & $\mathrm{FeO}^{2+}+\mathrm{OH}^{\cdot}+\mathrm{H}^{+} \rightarrow \mathrm{Fe}^{3+}+\mathrm{H}_{2} \mathrm{O}_{2}$ & $1.0 \times 10^{7}$ & Jacobsen et al. (1998) \\
\hline K12 & $\mathrm{FeO}^{2+}+\mathrm{H}_{2} \mathrm{O}_{2} \rightarrow \mathrm{Fe}^{3+}+\mathrm{HO}_{2}^{-}+\mathrm{OH}^{-}$ & $1.0 \times 10^{4}$ & Jacobsen et al. (1998) \\
\hline K13 & $\mathrm{FeO}^{2+}+\mathrm{HO}_{2}^{-} \rightarrow \mathrm{Fe}^{3+}+\mathrm{O}_{2}+\mathrm{OH}^{-}$ & $2.0 \times 10^{6}$ & Jacobsen et al. (1998) \\
\hline \multicolumn{4}{|c|}{$\mathrm{HO}_{2}^{\prime} / \mathrm{O}_{2}^{-\cdot}$ reactions } \\
\hline K14 & $\mathrm{HO}_{2}+\mathrm{HO}_{2} \rightarrow \mathrm{H}_{2} \mathrm{O}_{2}+\mathrm{O}_{2}$ & $8.3 \times 10^{5}$ & Bielski et al. (1985) \\
\hline K15 & $\mathrm{HO}_{2}^{2}+\mathrm{O}_{2}+\mathrm{H}^{+} \rightarrow \mathrm{H}_{2} \mathrm{O}_{2}+\mathrm{O}_{2}$ & $9.7 \times 10^{7}$ & Bielski et al. (1985) \\
\hline K16 & $\mathrm{CO}_{2}^{-}+\mathrm{O}_{2} \rightarrow \mathrm{CO}_{2}+\mathrm{O}_{2}^{-}$ & $2.4 \times 10^{9}$ & Sedlak and Hoigné (1993) \\
\hline \multicolumn{4}{|c|}{ Oxalate reactions } \\
\hline $\mathrm{K} 17 *$ & $\mathrm{Fe}\left(\mathrm{C}_{2} \mathrm{O}_{4}\right)_{n}^{3-2 n}+\mathrm{O}_{2}^{-\cdot} \rightarrow \mathrm{Fe}\left(\mathrm{C}_{2} \mathrm{O}_{4}\right)_{n}^{2-2 n}+\mathrm{O}_{2}$ & $1.0 \times 10^{6}$ & Sedlak and Hoigné (1993) \\
\hline $\mathrm{K} 18^{*}$ & $\mathrm{Fe}\left(\mathrm{C}_{2} \mathrm{O}_{4}\right)_{n}^{3-2 n}+\mathrm{HO}_{2} \rightarrow \mathrm{Fe}\left(\mathrm{C}_{2} \mathrm{O}_{4}\right)_{n}^{2-2 n}+\mathrm{O}_{2}+\mathrm{H}^{+}$ & $1.2 \times 10^{5}$ & Sedlak and Hoigné (1993) \\
\hline K19 & $\mathrm{C}_{2} \mathrm{O}_{4}^{2-}+\mathrm{OH}^{\cdot} \rightarrow \mathrm{OH}^{-}+\mathrm{C}_{2} \mathrm{O}_{4}^{-}$ & $5.3 \times 10^{6}$ & Getoff et al. (1971) \\
\hline K20 & $\mathrm{C}_{2} \mathrm{O}_{4}^{2-}+\mathrm{NO}_{3} \rightarrow \mathrm{NO}_{3}^{-}+\mathrm{C}_{2} \mathrm{O}_{4}^{-}$ & $2.2 \times 10^{8}$ & Raabe (1996) \\
\hline $\mathrm{K} 21$ & $\mathrm{C}_{2} \mathrm{O}_{4}^{2-}+\mathrm{O}_{2} \rightarrow 2 \mathrm{CO}_{2}+\mathrm{O}_{2}^{-}$ & $2.0 \times 10^{9}$ & CAPRAM \\
\hline
\end{tabular}

$* n=1,2$.

are the reactions with $\mathrm{H}_{2} \mathrm{O}_{2}$, ozone $\left(\mathrm{O}_{3}\right)$, nitrate $\left(\mathrm{NO}_{3}\right)$, and superoxide/hydroperoxide radicals. Based on this reaction mechanism $\mathrm{Fe}(\mathrm{II})$ is mainly produced during the day and is oxidized at night. Since Fe(II) and Fe(III) have very different solubility in ambient aqueous solutions, photochemical/chemical cycling of the two different forms of Fe may prove to increase the total amount of $\mathrm{Fe}_{\mathrm{d}}$ in mineral aerosols and have considerable effect on marine ecosystem productivity.

\section{Results}

\subsection{Atmospheric concentrations of oxalate}

Past studies have shown that surface level oxalate concentrations range from $\sim 10$ to $100 \mathrm{ng} \mathrm{m}^{-3}$ in rural and oceanic locations (Sciare et al., 2009) to greater than $1000 \mathrm{ng} \mathrm{m}^{-3}$ in urban and highly polluted regions (Kawamura and Ikushima, 1993; Legrand et al., 2007). In order to determine the accuracy of GEOS-Chem/ $/ \mathrm{Fe}_{\mathrm{d}}$-predicted surface oxalate concentrations, model-predicted values are compared to a global dataset of oxalate concentration measurements (Myriokefalitakis et al., 2011). Figure 2 shows that model-predicted oxalate concentrations compare relatively well to surface measurements and overall can reproduce the majority of 
Table 4. Aqueous-phase reactions in GEOS-Chem/ $/ \mathrm{Fe}_{\mathrm{d}}$ and their equilibrium constants.

\begin{tabular}{|c|c|c|c|c|c|}
\hline & $\begin{array}{l}\text { Equilibrium } \\
\text { Reaction }\end{array}$ & $\begin{array}{l}\text { Equilibrium } \\
\text { Constants* }\end{array}$ & $\begin{array}{l}K_{298}(\text { forward}) \\
\mathrm{M}^{-n} \mathrm{~s}^{-1}\end{array}$ & $\begin{array}{l}K_{298} \text { (back) } \\
\mathrm{M}^{-n} \mathrm{~s}^{-1}\end{array}$ & Source \\
\hline E1 & $\mathrm{Fe}(\mathrm{OH})_{3}(\mathrm{~s})+3 \mathrm{H}^{+} \leftrightarrow \mathrm{Fe}^{3+}+3 \mathrm{H}_{2} \mathrm{O}$ & $9.1 \times 10^{3}$ & & & Stumm and Morgan (1981) \\
\hline E2 & $\mathrm{Fe}^{3+}+\mathrm{SO}_{4}^{2-} \leftrightarrow \mathrm{FeSO}_{4}^{+}$ & $1.2 \times 10^{2}$ & $3.2 \times 10^{3}$ & $2.7 \times 10^{1}$ & Jayson et al. (1973) \\
\hline E3 & $\mathrm{Fe}^{3+}+\mathrm{Cl}^{-} \leftrightarrow \mathrm{FeCl}^{2+}$ & 5.2 & 4.8 & $9.2 \times 10^{-1}$ & Deguillaume et al. (2005) \\
\hline $\mathrm{E} 4$ & $\mathrm{Fe}^{3+}+\mathrm{H}_{2} \mathrm{O} \leftrightarrow \mathrm{Fe}(\mathrm{OH})^{2+}+\mathrm{H}^{+}$ & $6.0 \times 10^{-3}$ & $2.6 \times 10^{6}$ & $4.3 \times 10^{8}$ & Brandt and van Eldik (1995) \\
\hline E5 & $\mathrm{Fe}(\mathrm{OH})^{2+}+\mathrm{H}_{2} \mathrm{O} \leftrightarrow \mathrm{Fe}(\mathrm{OH})_{2}^{+}+\mathrm{H}^{+}$ & $9.8 \times 10^{-4}$ & $1.2 \times 10^{5}$ & $1.2 \times 10^{8}$ & Brandt and van Eldik (1995) \\
\hline E6 & $\mathrm{HO}_{2} \leftrightarrow \mathrm{O}_{2}^{-}+\mathrm{H}^{+}$ & $1.6 \times 10^{-5}$ & $8.0 \times 10^{5}$ & $5.0 \times 10^{10}$ & Bielski et al. (1985) \\
\hline E7 & $\mathrm{H}_{2} \mathrm{C}_{2} \mathrm{O}_{4} \leftrightarrow \mathrm{H}^{+}+\mathrm{HC}_{2} \mathrm{O}_{4}^{-}$ & $6.4 \times 10^{-2}$ & $3.2 \times 10^{9}$ & $5.0 \times 10^{10}$ & Meyerstein (1971) \\
\hline E8 & $\mathrm{HC}_{2} \mathrm{O}_{4}^{-} \leftrightarrow \mathrm{H}^{+}+\mathrm{C}_{2} \mathrm{O}_{4}^{2-}$ & $5.3 \times 10^{-5}$ & $2.6 \times 10^{6}$ & $5.0 \times 10^{10}$ & Meyerstein (1971) \\
\hline E9 & $\mathrm{Fe}^{3+}+\mathrm{C}_{2} \mathrm{O}_{4}^{2-} \leftrightarrow \mathrm{Fe}\left(\mathrm{C}_{2} \mathrm{O}_{4}\right)^{+}$ & $2.5 \times 10^{9}$ & $7.5 \times 10^{6}$ & $3.0 \times 10^{-3}$ & Deguillaume et al. (2005) \\
\hline E10 & $\mathrm{Fe}\left(\mathrm{C}_{2} \mathrm{O}_{4}\right)^{+}+\mathrm{C}_{2} \mathrm{O}_{4}^{2-} \leftrightarrow \mathrm{Fe}\left(\mathrm{C}_{2} \mathrm{O}_{4}\right)_{2}^{-}$ & $6.3 \times 10^{6}$ & $3.0 \times 10^{-3}$ & $1.9 \times 10^{4}$ & Deguillaume et al. (2005) \\
\hline E11 & $\mathrm{Fe}\left(\mathrm{C}_{2} \mathrm{O}_{4}\right)_{2}^{-}+\mathrm{C}_{2} \mathrm{O}_{4}^{2-} \leftrightarrow \mathrm{Fe}\left(\mathrm{C}_{2} \mathrm{O}_{4}\right)_{3}^{3-}$ & $1.6 \times 10^{4}$ & $4.8 \times 10^{1}$ & $3.0 \times 10^{-3}$ & Deguillaume et al. (2005) \\
\hline
\end{tabular}

* Equilibrium constants are given in units of $\mathrm{mol} \mathrm{kg}^{-1}$.

measured oxalate concentrations within a factor of 2. Note that only for the purpose of comparison oxalate concentrations in Fig. 2 are calculated using model-predicted total sulfate (not only dust-sulfate) concentrations. This figure also shows that the model tends to over-predict the low concentrations of oxalate measured over remote oceanic regions. Such over-predictions of oxalate concentrations by GEOS$\mathrm{Chem} / \mathrm{Fe}_{\mathrm{d}}$ are associated with DMS emissions and are not related to the suggested natural oceanic sources of oxalate precursor gases (e.g., glyoxal) (e.g., Kawamura et al., 1996; Myriokefalitakis et al., 2008; Sinreich et al., 2010; Volkamer et al., 2010). Figures S1 and S2 show the spatial distribution of the model-predicted seasonally averaged surface level total oxalate concentrations and oxalate concentrations associated with mineral dust. When comparing Figs. S1 and S2 it can be seen that near the dust source regions, a noticeable fraction of the total oxalate is associated with dust. However, away from the dust sources the concentration of total oxalate is considerably higher compared to the amount of oxalate associated with mineral dust. Therefore, the excessive amounts of oxalate over remote oceanic regions seen in Fig. 2 is not likely to be associated with mineral dust and have a minor effect on Fe dissolution kinetics. Overall, Figs. 2, S1 and S2 show that the mechanism used in the current study to estimate oxalate concentrations is suitable for the prediction of the effect of organic compounds on Fe dissolution kinetics within mineral dust.

\section{2 $\quad \mathrm{Fe}_{\mathrm{d}}$ deposition}

\subsubsection{Total $\mathrm{Fe}_{\mathrm{d}}$ deposition}

Figure 3 shows the GEOS-Chem/ $\mathrm{Fe}_{\mathrm{d}}$-predicted seasonally averaged $\mathrm{Fe}_{\mathrm{d}}$ deposition (including proton- and oxalatepromoted dissolution process and $\mathrm{Fe}(\mathrm{II}) / \mathrm{Fe}(\mathrm{III})$ redox cycling) rates during the year-long simulation. Overall, GEOS$\mathrm{Chem} / \mathrm{Fe}_{\mathrm{d}}$ predicted that $\sim 0.26 \mathrm{Tg}\left(1 \mathrm{Tg}=10^{12} \mathrm{~g}\right)$ of $\mathrm{Fe}_{\mathrm{d}}$ was deposited to the global oceans during the simulated time

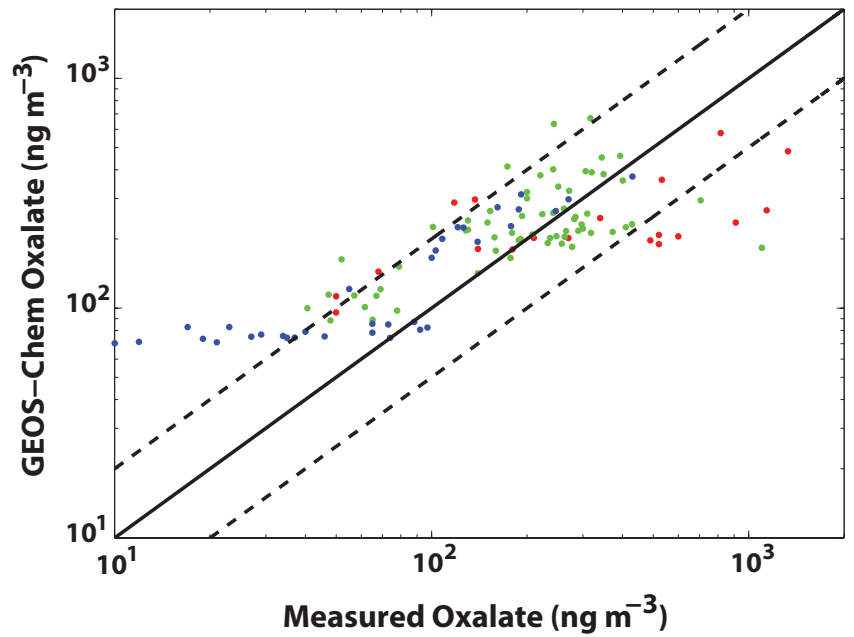

Fig. 2. Model-predicted surface level oxalate concentrations relative to measurements conducted in urban (red dots), rural (green), and remote oceanic (blue) regions. Observed surface level oxalate concentrations are taken from Myriokefalitakis et al. (2011) and references within. The solid black line illustrates the $1: 1$ comparison, and the two dashed lines are the $1: 2$ and $2: 1$ comparisons.

period. This magnitude compares well to recent modeling studies (Luo et al., 2008; Luo and Gao, 2010; Okin et al., 2011) that predicted total annual $\mathrm{Fe}_{\mathrm{d}}$ deposition to the global oceans between 0.21 and $0.41 \mathrm{Tg}$. The magnitude of $\mathrm{Fe}_{\mathrm{d}}$ deposition to the North Atlantic Ocean is large year-round, with highest fluxes up to $100 \mu \mathrm{g} \mathrm{m}^{-2} \mathrm{day}^{-1}$. Figure 3 also shows that seasonally averaged $\mathrm{Fe}_{\mathrm{d}}$ deposition rates to the North Pacific Ocean, in close proximity to the Asian continent, are elevated during the spring and summer months $\left(>10 \mu \mathrm{g} \mathrm{m}^{-2}\right.$ day $\left.^{-1}\right)$ when model-predicted mineral dust emissions are at a maximum. According to Fig. 3 the highest seasonally averaged $\mathrm{Fe}_{\mathrm{d}}$ deposition rates to the HNLC waters of the subarctic North Pacific Ocean (here considered to be north of the Subarctic Current $\left(\sim 40^{\circ} \mathrm{N}\right)$, Peterson et al., 


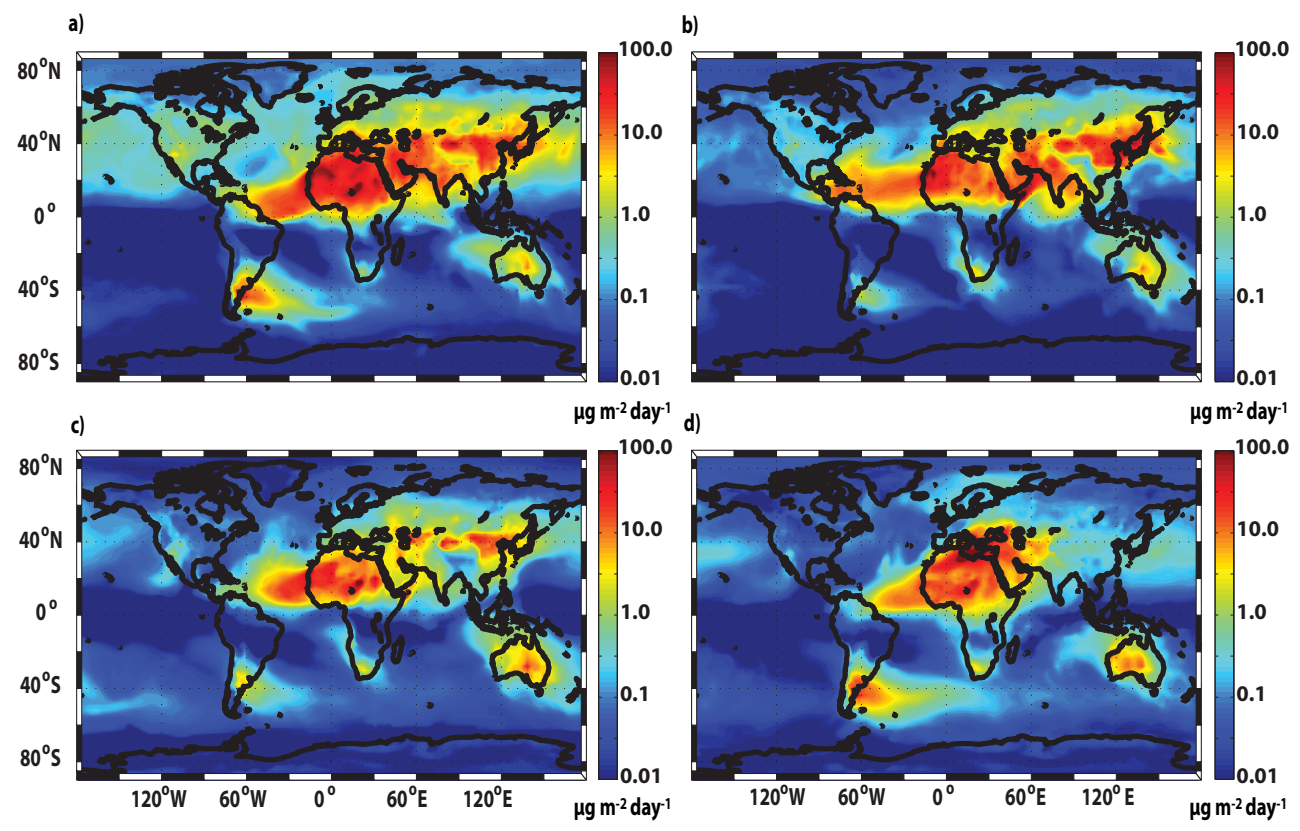

Fig. 3. Model-predicted seasonally averaged $\mathrm{Fe}_{\mathrm{d}}$ deposition rates $\left(\mu \mathrm{g} \mathrm{m} \mathrm{m}^{-2} \mathrm{day}^{-1}\right.$ ) for (a) March-May (MAM), (b) June-August (JJA), (c) September-November (SON), and (d) December-February (DJF).

2005) also occur during the spring and summer months and could provide an important source of bioavailable $\mathrm{Fe}$ to these Fe-depleted surface waters. Overall, GEOS-Chem/Fe $\mathrm{F}$ predicted $\sim 5 \%$ of the total annual $\mathrm{Fe}_{\mathrm{d}}$ deposited to the global oceans was supplied to the HNLC regions of the North Pacific Ocean.

From Fig. 3 it can be seen that in the Southern Hemisphere the highest rates of $\mathrm{Fe}_{\mathrm{d}}$ deposition occur downwind from the dust source regions of Australia and South America. According to this figure, there is a distinct seasonality in $\mathrm{Fe}_{\mathrm{d}}$ deposition rates to the Southern Ocean, associated with South American dust sources (predominately the deserts of Patagonia), with highest fluxes predicted to occur during the austral summer and fall months. $\mathrm{Fe}_{\mathrm{d}}$ deposition, associated with Australian dust, is less seasonal in comparison to South American sources, with more constant year-round $\mathrm{Fe}_{\mathrm{d}}$ deposition rates. The largest fluxes of bioavailable Fe deposited to the HNLC regions of the Southern Ocean (considered to be south of the Antarctic Circumpolar Current $\left(\sim 42^{\circ} \mathrm{S}\right)$, Boyd et al., 2007) are predicted to be from Patagonian dust sources with rates reaching $10 \mu \mathrm{g} \mathrm{m}^{-2}$ day $^{-1}$ during the austral summer and fall. Overall, $\sim 7 \%$ of the total annual magnitude of $\mathrm{Fe}_{\mathrm{d}}$ deposited to the global oceans was supplied to the HNLC regions of the Southern Ocean.

To quantify the importance of the atmospheric chemical transformation of mineral-Fe, studies often report either fluxes of $\mathrm{Fe}_{\mathrm{d}}$ or DIFs at the moment of mineral dust deposition. Figure 4 shows that DIF values, simulated by GEOS$\mathrm{Chem} / \mathrm{Fe}_{\mathrm{d}}$, are highly variable both spatially and temporally. In general, DIF values remain lower near the dust source regions but increase downwind as acidic trace gases and organic compounds are expected to enhance $\mathrm{Fe}$ mobilization. The highest DIFs are predicted over the regions characterized by low concentrations of dust and high amounts of anthropogenic pollution (and oxalate concentration), e.g., during the summer months over the North Pacific Ocean, off the east coast of Asia. On the other hand, Fig. 4 shows that DIFs remain lower over regions frequently influenced by large dust outbreaks, e.g., over the North Atlantic Ocean, downwind from the source regions of North Africa. Our modelpredicted $\mathrm{Fe}_{\mathrm{d}}$ deposition fluxes and DIF values are highly dependent on the prescribed initial solubility of mineral $\mathrm{Fe}$ at the source region. This value is particularly important in pristine regions where atmospheric processing is less efficient for $\mathrm{Fe}$ dissolution in mineral dust particles. While DIF values may vary between dust source regions, our initial DIF values were prescribed based on the data of $\mathrm{Fe}_{\mathrm{d}}$ from the reactive and poorly crystalline pool of $\mathrm{Fe}$ in dust precursor samples from the Sahara and Sahel regions of North Africa (Shi et al., 2012). Due to the importance of prescribed DIFs on $\mathrm{Fe}_{\mathrm{d}} \mathrm{de}-$ position fluxes, and the potential variability of this value between different dust source regions, it is suggested that future studies should be conducted to better characterize this value for the global dust source regions. Overall, Fig. 4 shows that DIF values can be used as an indication of the overall effect of atmospheric chemical processing of mineral-Fe. However, one should not associate high DIFs with large amounts of $\mathrm{Fe}_{\mathrm{d}}$. When compared to Fig. 3, Fig. 4 shows that some regions characterized by the highest values of DIF also show some of the lowest total fluxes of $\mathrm{Fe}_{\mathrm{d}}$, e.g., the HNLC region 

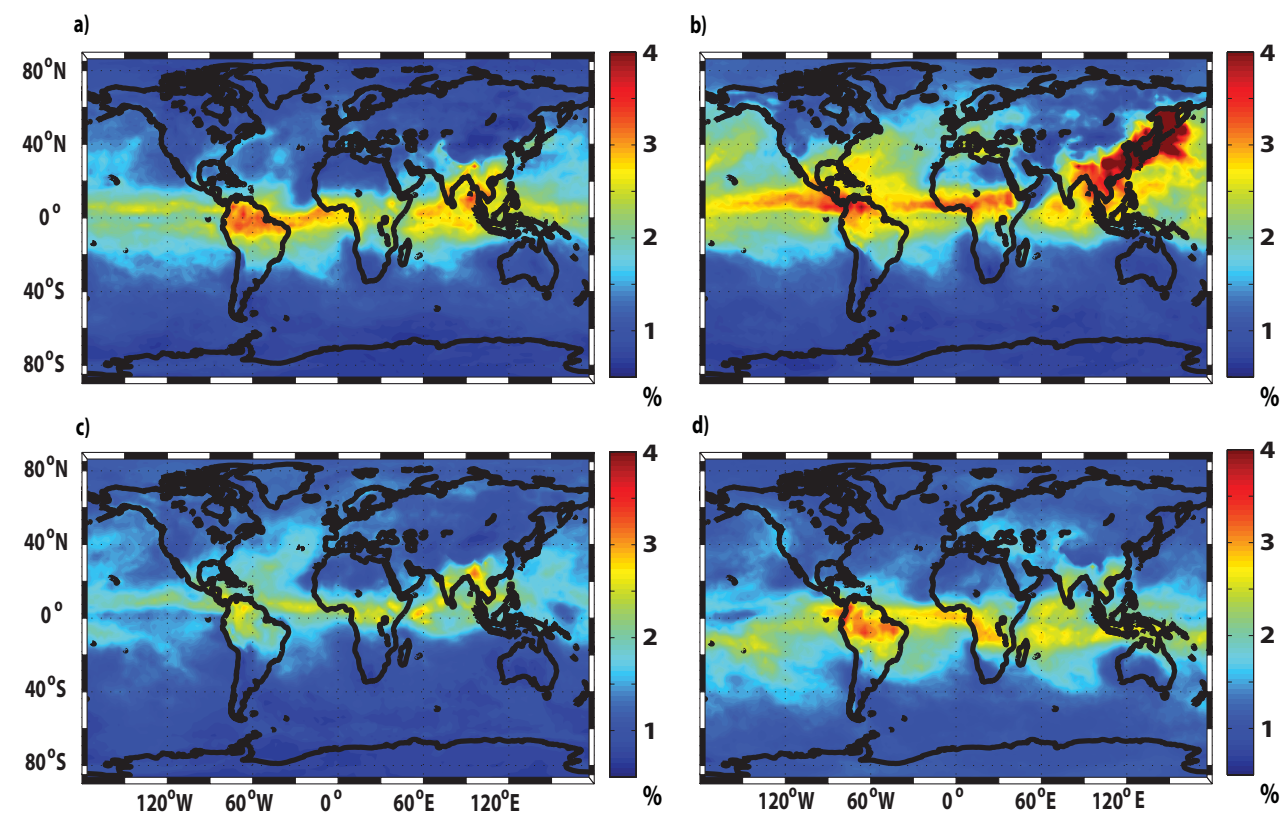

Fig. 4. Model-predicted seasonally averaged DIF values (\%) in deposited mineral dust for (a) March-May (MAM), (b) June-August (JJA), (c) September-November (SON), and (d) December-February (DJF).
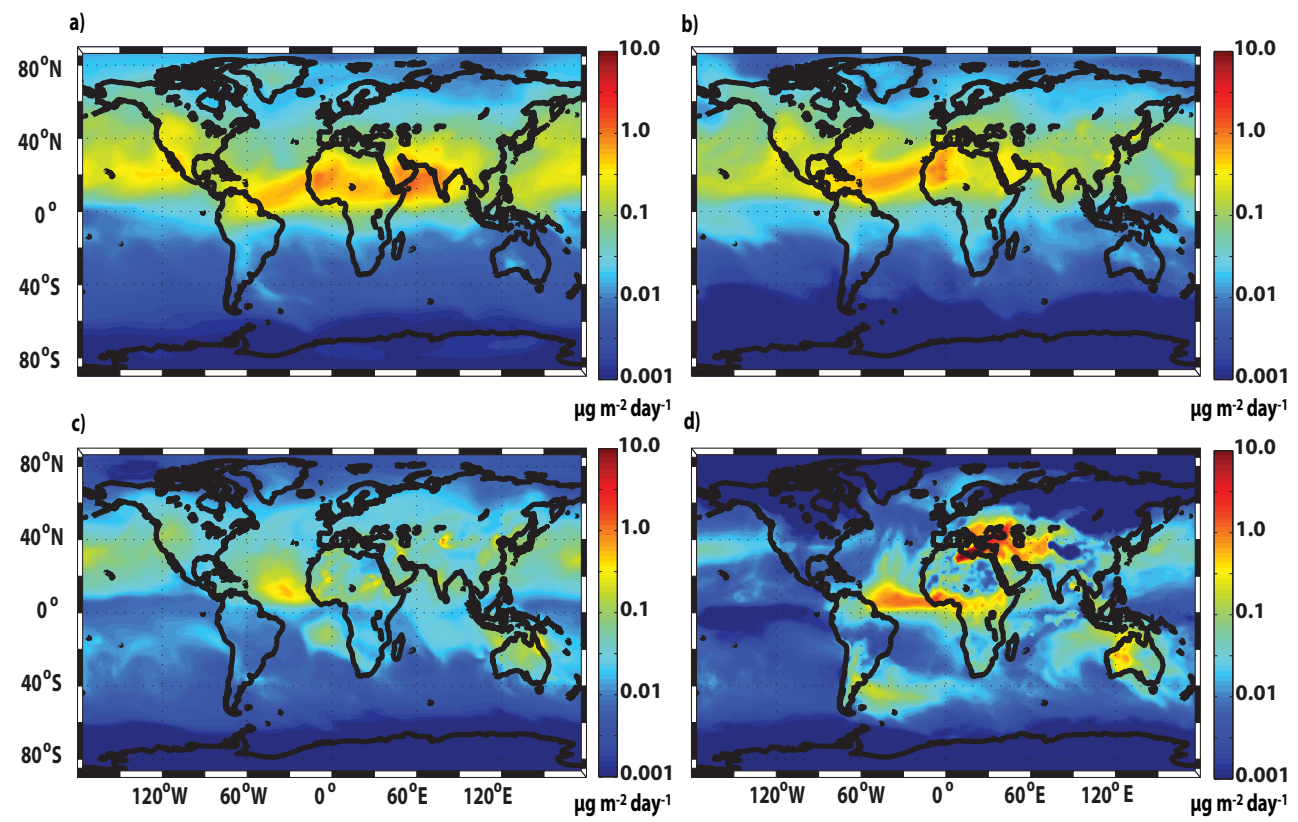

Fig. 5. Model-predicted seasonally averaged Fe(II) deposition rates $\left(\mu \mathrm{g} \mathrm{m} \mathrm{m}^{-2} \mathrm{day}^{-1}\right.$ ) for (a) March-May (MAM), (b) June-August (JJA), (c) September-November (SON), and (d) December-February (DJF).

of the equatorial Pacific. Therefore, DIF alone are poor proxies for the importance of the atmospheric transport pathways for $\mathrm{Fe}_{\mathrm{d}}$ deposition to the global oceans. When the biogeochemical cycling of dust-Fe is examined, both fluxes of $\mathrm{Fe}_{\mathrm{d}}$ and DIFs should be presented.

\subsection{2 $\mathrm{Fe}(\mathrm{II})$ deposition}

Figure 5 shows GEOS-Chem/ $/ \mathrm{Fe}_{\mathrm{d}}$-predicted seasonally averaged (over both day- and nighttime hours) $\mathrm{Fe}(\mathrm{II})$ deposition rates. In the Northern Hemisphere the largest seasonally averaged deposition rates of $\mathrm{Fe}$ (II) $\left(>1.0 \mu \mathrm{g} \mathrm{m}^{-2} \mathrm{day}^{-1}\right)$ occur in the North Atlantic Ocean, associated with mineral 
Table 5. Comparison of model-predicted $\mathrm{Fe}_{\mathrm{d}}$ values to ambient data.

\begin{tabular}{|c|c|c|c|c|}
\hline \multirow[b]{2}{*}{ Measurement Campaign } & \multicolumn{4}{|c|}{$\mathrm{Fe}(\mathrm{III})\left(\mathrm{ng} \mathrm{m}^{-3}\right)$} \\
\hline & $R$ & Bias & RMSE & $\mathrm{NMB}^{\mathrm{a}}$ \\
\hline MP01 (Atlantic Ocean) ${ }^{b}$ & 0.72 & -0.06 & 0.04 & -10.70 \\
\hline MP02 (Pacific Ocean) ${ }^{\mathrm{c}}$ & 0.64 & -0.12 & 0.04 & -26.14 \\
\hline MP03 (Atlantic Ocean) ${ }^{b}$ & 0.84 & 1.50 & 2.53 & 135.38 \\
\hline MP05 (Pacific Ocean) ${ }^{c}$ & 0.58 & -0.06 & 0.01 & -49.77 \\
\hline \multirow[t]{2}{*}{ Trapp et al. (2010) (Atlantic Ocean) } & 0.70 & -0.52 & 1.41 & -20.64 \\
\hline & \multicolumn{4}{|c|}{$\mathrm{Fe}(\mathrm{II})\left(\mathrm{ng} \mathrm{m}^{-3}\right)$} \\
\hline Measurement Campaign & $R$ & Bias & RMSE & $\mathrm{NMB}^{\mathrm{a}}$ \\
\hline MP01 (Atlantic Ocean) ${ }^{b}$ & 0.48 & -0.14 & 0.39 & -24.75 \\
\hline MP02 (Pacific Ocean) ${ }^{\mathrm{c}}$ & 0.61 & -0.22 & 0.87 & -17.30 \\
\hline MP03 (Atlantic Ocean) ${ }^{b}$ & 0.65 & 0.31 & 0.33 & 83.22 \\
\hline MP05 (Pacific Ocean) ${ }^{\mathrm{c}}$ & 0.78 & -0.12 & 0.01 & -46.56 \\
\hline \multirow[t]{2}{*}{ Trapp et al. (2010) (Atlantic Ocean) } & 0.62 & -0.89 & 1.73 & -35.44 \\
\hline & \multicolumn{4}{|c|}{ DIF (\%) } \\
\hline Measurement Campaign & $R$ & Bias & RMSE & $\mathrm{NMB}^{\mathrm{a}}$ \\
\hline MP01 (Atlantic Ocean) ${ }^{b}$ & 0.63 & -8.48 & 14.17 & -51.91 \\
\hline MP02 (Pacific Ocean) ${ }^{c}$ & 0.46 & -0.30 & 0.26 & -18.50 \\
\hline MP03 (Atlantic Ocean) ${ }^{b}$ & 0.53 & -0.85 & 1.15 & -37.13 \\
\hline MP05 (Pacific Ocean) ${ }^{\mathrm{c}}$ & 0.41 & -2.86 & 11.24 & -32.58 \\
\hline
\end{tabular}

${ }^{a}$ NMB is in percent. ${ }^{b}$ Chen and Siefert (2004). ${ }^{c}$ Chen (2004).

dust transport from the Sahara. A significant source of Fe(II) to the North Pacific Ocean is predicted to be dust outflow from the Asian sources, particularly during spring and summer months (from 0.1 to $1.0 \mu \mathrm{g} \mathrm{m}^{-2}$ day $^{-1}$ ). In the Southern Hemisphere, $\mathrm{Fe}$ (II) fluxes are minor compared to the Northern Hemisphere. This is largely due the combination of lower dust abundances and the pristine nature of this region. $\mathrm{Fe}(\mathrm{II})$ deposition rates to the Southern Ocean, primarily from Patagonian dust sources, were predicted to be at a maximum during the austral summer (from 0.01 to $1.0 \mu \mathrm{g} \mathrm{m}^{-2}$ day $^{-1}$ ) associated with highest dust emission rates.

\subsubsection{Comparison of model results with observations}

To assess how well the model can capture the complex photochemical redox cycling of Fe in atmospheric waters, daily-averaged model-predicted surface concentrations of $\mathrm{Fe}(\mathrm{II})$ and $\mathrm{Fe}(\mathrm{III})$ were compared to ship-based measurements over the regions largely influenced by dust (Chen and Siefert, 2004). The measurements were chosen based on the availability of daily $\mathrm{Fe}$ (II) and $\mathrm{Fe}(\mathrm{III})$ data. The time series in Fig. 6 show that GEOS-Chem/ $/ \mathrm{Fe}_{\mathrm{d}}$ can generally capture the temporal pattern of measured surface concentrations of $\mathrm{Fe}$ (II) and $\mathrm{Fe}$ (III) both close to (MP03) and downwind (MP01) from the Sahara. However, data analysis showed (see Table 5) that compared to the measurements of Chen and Siefert (2004), GEOS-Chem/ $/ \mathrm{Fe}_{\mathrm{d}}$ over-predicted
$\mathrm{Fe}(\mathrm{III})(\mathrm{NMB}=135 \%)$ and $\mathrm{Fe}(\mathrm{II})(\mathrm{NMB}=83 \%)$ concentrations just off the coast of northern Africa and slightly underpredicted $\mathrm{Fe}$ (III) $(\mathrm{NMB}=-10 \%)$ and $\mathrm{Fe}$ (II) $(\mathrm{NMB}=$ $-25 \%$ ) concentrations over the western portion of the North Atlantic Ocean. Further evaluation revealed that at least some of the discrepancies between model-predicted and measured values of $\mathrm{Fe}_{\mathrm{d}}$ were likely associated with inaccuracies in simulated mineral dust concentrations: GEOSChem over-predicted total $\mathrm{Fe}$ concentrations close to the Sahara $(\mathrm{MP03} \mathrm{NMB}=130 \%)$ and underpredicted farther downwind (MP01 NMB $=-25 \%$ ). In addition to mineral dust concentrations, large RMSE values may be caused by missing physicochemical processes influencing $\mathrm{Fe}_{\mathrm{d}}$ production within mineral dust, combustion and biomass burning sources of $\mathrm{Fe}_{\mathrm{d}}$ not included in GEOS-Chem/Fe $\mathrm{d}$, and the time interval (day vs. night) when the measurements were collected. GEOS-Chem/ $/ \mathrm{Fe}_{\mathrm{d}}$-predicted total $\mathrm{Fe}_{\mathrm{d}}$ and its partitioning between $\mathrm{Fe}$ (II) and $\mathrm{Fe}$ (III) species (not shown) may vary considerably with the amount of incoming radiation. Throughout the day up to $90 \%$ of $\mathrm{Fe}_{\mathrm{d}}$ could reside in the $\mathrm{Fe}$ (II) form, while during nighttime conditions $\mathrm{Fe}$ (III) is expected to be the predominant form of $\mathrm{Fe}_{\mathrm{d}}$ (e.g., Zhu et al., 1997; Siefert et al., 1998). This modeling result indicates that future studies should report the time of day when $\mathrm{Fe}(\mathrm{II}) / \mathrm{Fe}(\mathrm{III})$ measurements where conducted. 

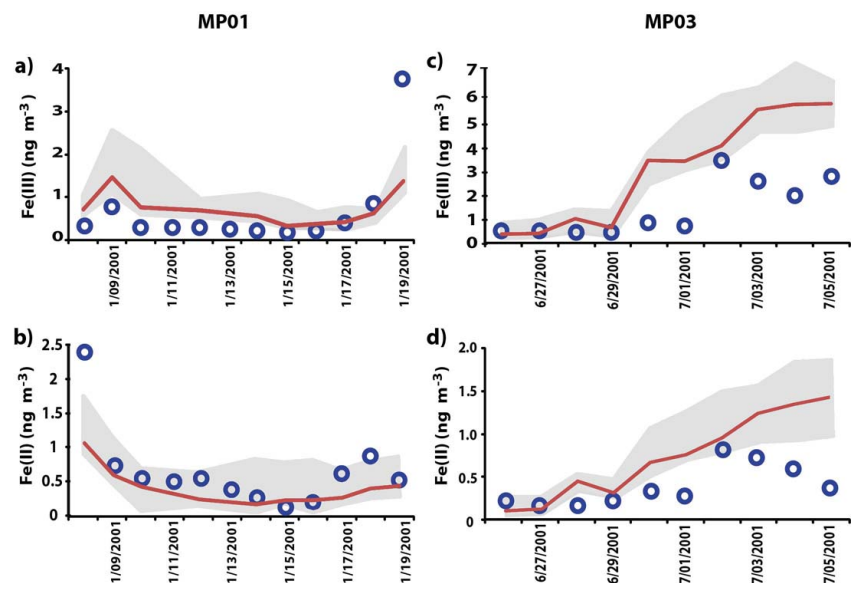

Fig. 6. Daily averaged baseline model-predicted (red line) and observed (blue open circles) surface level concentrations of $(\mathbf{a}, \mathbf{c})$ $\mathrm{Fe}$ (III) $\left(\mathrm{ng} \mathrm{m}^{-3}\right)$ and $(\mathbf{b}, \mathbf{d}) \mathrm{Fe}$ (II) $\left(\mathrm{ng} \mathrm{m}^{-3}\right)$ from 8 January to 19 January 2001 (MP01) - left column - and from 26 June to 5 July 2001 (MP03) - right column. The shaded area illustrates the range of model-predicted $\mathrm{Fe}(\mathrm{II}) / \mathrm{Fe}$ (III) concentrations when assuming illite and goethite as the major Fe-containing mineral within dust. Model-predicted concentrations are from the first model grid above the ocean surface.

\subsubsection{Oxalate-promoted Fe dissolution}

The influence of oxalate on seasonally averaged $\mathrm{Fe}_{\mathrm{d}}$ deposition rates is shown in Fig. 7 as the percent difference between the Fe dissolution scheme developed in this study and the proton-promoted Fe dissolution of Meskhidze et al. (2005). Our calculations suggest that globally, the implementation of oxalate-promoted $\mathrm{Fe}$ dissolution and the redox cycling between $\mathrm{Fe}(\mathrm{II})$ and $\mathrm{Fe}$ (III) led to $\sim 75 \%$ increase in the $\mathrm{Fe}_{\mathrm{d}}$ deposition to the oceans and depict complex spatiotemporal patterns. Figure 7 shows that over the oceanic regions predominantly influenced by anthropogenic pollution (e.g., over the tropical North Atlantic, northern Indian, equatorial Pacific, and North Pacific Oceans) oxalate-promoted Fe dissolution had a large effect on $\mathrm{Fe}_{\mathrm{d}}$ deposition rates, while over the pristine regions (e.g., the Southern Ocean) the effect is more modest.

\subsubsection{Analysis of model sensitivity to Fe-containing minerals}

By prescribing Fe to different minerals (i.e., goethite and illite) here we present sensitivity calculations to assess how the assumption regarding different $\mathrm{Fe}$-containing minerals can affect model-predicted $\mathrm{Fe}_{\mathrm{d}}$ fluxes. Figure 8 shows the percent difference in $\mathrm{Fe}_{\mathrm{d}}$ deposition rates between the baseline model simulations and the sensitivity studies. According to our calculations, the assumption of goethite to be the major Fe-containing mineral reduces the total amount of $\mathrm{Fe}_{\mathrm{d}}$ deposited to the global oceans by $40 \%$ and $50 \%$, while the assumption of illite increased $\mathrm{Fe}_{\mathrm{d}}$ fluxes by $110 \%$ and $150 \%$ for January and July, respectively. To assess how well the model can predict surface concentrations of Fe(II) and $\mathrm{Fe}(\mathrm{III})$, when assuming goethite and illite as the major Fe-containing minerals, daily averaged simulated values were compared to the ship-based measurements of Chen and Siefert (2004) (Tables S3 and S4). Such different responses of $\mathrm{Fe}_{\mathrm{d}}$ concentrations and deposition rates to the assumption of Fe-containing minerals within dust suggest that the explicit representation of dust mineralogy and better quantification of $\mathrm{Fe}$ content within individual Fe-containing minerals are needed for the improved description of the biogeochemical cycling of mineral-Fe in global climate models.

\subsubsection{Comparison between a priori assumptions and explicitly calculated $\mathrm{Fe}_{d}$ deposition rates}

Global climate and ocean biogeochemistry models that do not have explicit treatments of $\mathrm{Fe}_{\mathrm{d}}$ production calculate fluxes of bioavailable Fe based on a prescribed DIF, often from 1 to $10 \%$ (e.g., Fung et al., 2000; Aumont et al., 2003; Gregg et al., 2003; Moore et al., 2004). In this section of the study, the differences in model-predicted $\mathrm{Fe}_{\mathrm{d}}$ deposition rates using an a priori assumption of $1 \%$ DIF ("assumed") and explicitly calculated $\mathrm{Fe}_{\mathrm{d}}$ values ("calculated") is examined. Figure 9 shows considerable spatiotemporal differences between seasonally averaged $\mathrm{Fe}_{\mathrm{d}}$ deposition rates for assumed and calculated $\mathrm{Fe}_{d}$ values. Over the HNLC waters of the subarctic North Pacific Ocean the calculated $\mathrm{Fe}_{\mathrm{d}}$ deposition rates are noticeably higher in the summer months (over $100 \%$ ) and lower during the winter months. In the HNLC region of the equatorial Pacific Ocean, the calculated $\mathrm{Fe}_{\mathrm{d}}$ deposition rates are higher year-round compared to the assumed ones, while in the HNLC waters of the Southern Ocean, the assumption of a $1 \%$ DIF can lead to $50-100 \%$ higher $\mathrm{Fe}_{\mathrm{d}}$ fluxes. Further data analysis shows that daily averaged $\mathrm{Fe}_{\mathrm{d}}$ fluxes in HNLC oceanic regions for calculated and assumed DIF values often differ by a factor of 5 or more. As individual dust deposition events may have a large influence on ocean biological productivity and the carbon cycle, this result suggests that in next generation earth system models every effort should be made for accurate characterization of $\mathrm{Fe}_{\mathrm{d}}$ in episodic dust plumes.

\section{Conclusions}

The deposition of mineral dust is an important supply pathway of $\mathrm{Fe}_{\mathrm{d}}$ to HNLC regions of the global oceans influencing marine ecosystem processes. In this study $\mathrm{Fe}_{\mathrm{d}} \mathrm{de}-$ position rates were calculated using the global 3-D model GEOS-Chem implemented with the most up-to-date dust$\mathrm{Fe}$ dissolution scheme. The original inorganic acid/pH dependent dust-Fe dissolution scheme was expanded through the addition of organic (oxalate)-promoted $\mathrm{Fe}$ dissolution 

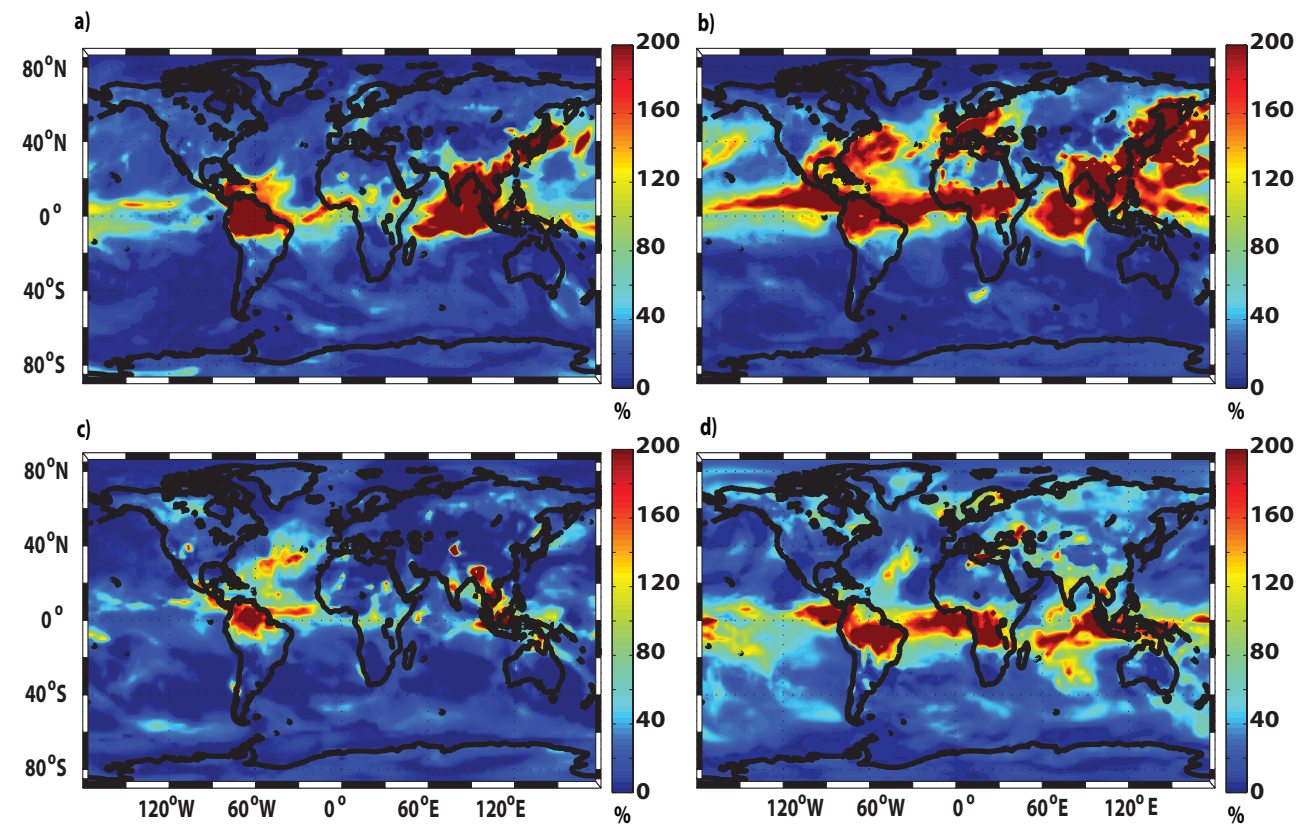

Fig. 7. Model-predicted percent change in seasonally averaged $\mathrm{Fe}_{\mathrm{d}}$ deposition rates due to the implementation of oxalate-promoted Fe dissolution for (a) March-May (MAM), (b) June-August (JJA), (c) September-November (SON), and (d) December-February (DJF).

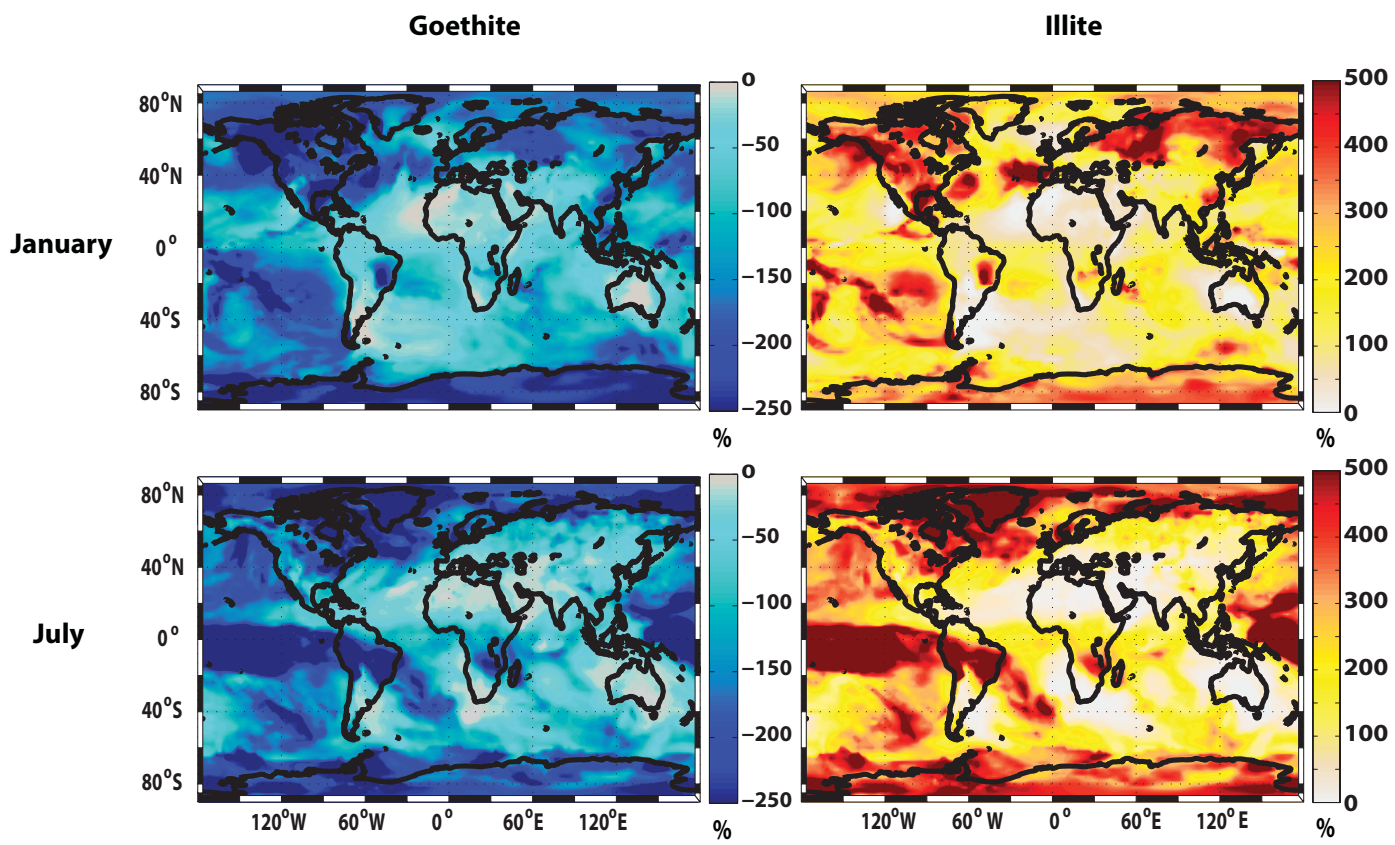

Fig. 8. Model-predicted percent changes (relative to baseline model runs) in $\mathrm{Fe}_{\mathrm{d}}$ deposition rates (\%) for January 2010 (top row) and July 2009 (bottom row) when all mineral-Fe is prescribed to be in goethite (left column) and illite (right column). Cold colors show the areas where $\mathrm{Fe}_{\mathrm{d}}$ deposition rates calculated during sensitivity studies are lower compared to baseline model simulations (hematite), warm colors indicate the opposite.

processes, photochemical redox cycling between Fe(II) and $\mathrm{Fe}(\mathrm{III})$, dissolution of different Fe-containing minerals, and detailed mineralogy of wind-blown dust from the major desert regions. The spatiotemporal variability of $\mathrm{Fe}_{\mathrm{d}}$ fluxes and DIF values were calculated from March 2009 to February 2010

During the year-long simulation the amount of modelpredicted $\mathrm{Fe}_{\mathrm{d}}$ deposited to the global oceans was $\sim 0.26 \mathrm{Tg}$. 

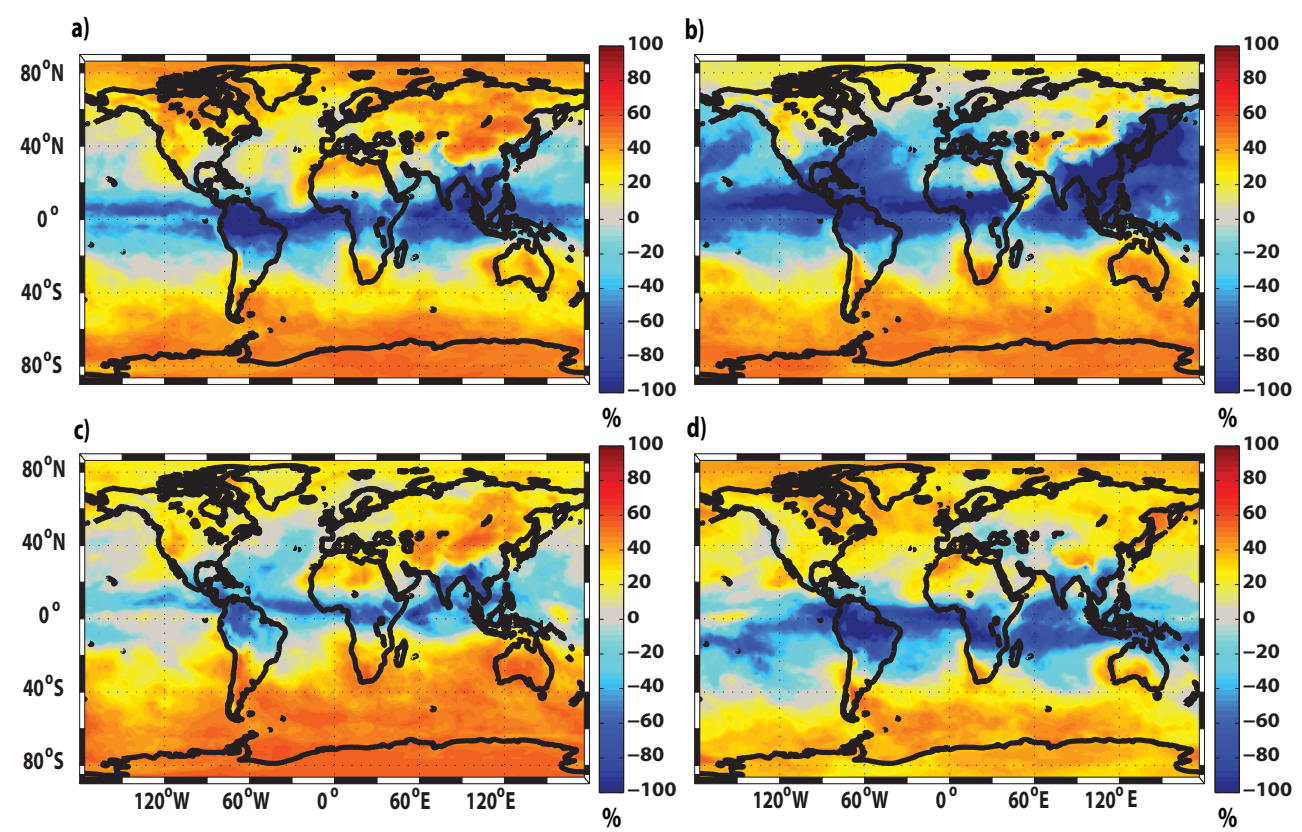

Fig. 9. Percent difference in seasonally averaged $\mathrm{Fe}_{\mathrm{d}}$ deposition rates using fixed a priori (1\%) DIF values and explicit calculations for (a) March-May (MAM), (b) June-August (JJA), (c) September-November (SON), and (d) December-February (DJF). Cold colors show the areas where the model-predicted $\mathrm{Fe}_{\mathrm{d}}$ deposition rates are higher compared to a prior assumptions, warm colors indicate the opposite.

GEOS-Chem/ $\mathrm{Fe}_{\mathrm{d}}$-predicted fluxes of $\mathrm{Fe}_{\mathrm{d}}$ ranged from $\sim 100 \mathrm{\mu g} \mathrm{m}^{-2}$ day $^{-1}$ in the North Atlantic Ocean to $<1 \mathrm{ng} \mathrm{m}^{-2} \mathrm{day}^{-1}$ in the remote regions of the South Pacific and Southern Oceans, highlighting the large spatiotemporal variability in fluxes of bioavailable $\mathrm{Fe}$ to the surface oceans. Model calculations show sizable differences in DIF values over different parts of the global oceans, indicating that the chemical processing of mineral dust (and subsequent Fe mobilization) can be a strong function of different chemical and physical characteristics, such as Fe-laden dust mass concentrations, mineralogy, the surface area of dust particles, atmospheric chemical composition, cloud processing, and meteorological variables. In close proximity to large dust emission source regions the model-predicted DIFs are typically low, as large dust plumes generally require high amounts of acidic trace gases to neutralize the buffering capacity of mineral dust. The regions with lower concentration of mineral dust and high amounts of pollutants inclined to have higher DIF values. However, such regions, even with substantial DIFs, are often characterized by minor fluxes of $\mathrm{Fe}_{\mathrm{d}}$. For completeness, we suggest that both $\mathrm{Fe}_{\mathrm{d}}$ deposition rates and DIF values be reported in future model simulations.

GEOS-Chem $/ \mathrm{Fe}_{\mathrm{d}}$ predictions of total $\mathrm{Fe}_{\mathrm{d}}$ and $\mathrm{Fe}(\mathrm{II}) / \mathrm{Fe}$ (III) partitioning were shown to compare relatively well with five measurement campaigns over various oceanic regions. Overall, the model was shown to capture the temporal variability and diurnal cycling between Fe(II) and $\mathrm{Fe}(\mathrm{III})$. However, it was revealed that model-predicted surface concentrations of $\mathrm{Fe}$ (III) and $\mathrm{Fe}$ (II) had positive biases close to the dust source regions and much smaller to even negative biases downwind. The suggested possible reasons for discrepancies between the model-predicted and observational data are associated with uncertainties in GEOS-Chem treatment of mineral dust (i.e., emission, transport, and deposition), missing sources of $\mathrm{Fe}_{\mathrm{d}}$ associated with anthropogenic combustion and biomass burning, omitted physicochemical processes potentially involved in the production of bioavailable Fe within mineral dust, and measurement uncertainties related to the time of day/incoming solar radiation.

Our calculations suggest that compared to model simulations when only proton-promoted Fe dissolution is considered, the addition of oxalate and $\mathrm{Fe}(\mathrm{II}) / \mathrm{Fe}$ (III) photochemical redox cycling increased the annual supply of $\mathrm{Fe}_{\mathrm{d}}$ to the global oceans by $\sim 75 \%$. The effect of oxalate-promoted Fe dissolution displayed large spatiotemporal variability. Marine environments influenced by anthropogenic air masses tended to show the largest increases in $\mathrm{Fe}_{\mathrm{d}}$ production due to oxalate-promoted $\mathrm{Fe}$ dissolution. In some regions of the tropical North Atlantic, northern Indian, equatorial Pacific, and North Pacific Oceans, the presence of oxalate in mineral aerosols increased $\mathrm{Fe}_{\mathrm{d}}$ deposition rates up to $200 \%$. While past studies have been focused on deriving total $\mathrm{Fe}_{\mathrm{d}}$ fluxes to different oceanic regions, the implementation of photochemical $\mathrm{Fe}(\mathrm{II}) / \mathrm{Fe}$ (III) redox cycling highlighted the important distinction between the daytime fluxes of $\mathrm{Fe}_{\mathrm{d}}$ (in both $\mathrm{Fe}(\mathrm{II})$ and $\mathrm{Fe}(\mathrm{III})$ forms) and nighttime fluxes of $\mathrm{Fe}_{\mathrm{d}}$ (largely in $\mathrm{Fe}$ (III) form). Future campaigns may consider the 
separation of daytime and nocturnal measurements of $\mathrm{Fe}_{\mathrm{d}}$ over the oceans. Model simulations also highlighted the importance of the improved understanding of Fe mineralogy in desert soils. Calculations suggest that due to the differences in dissolution rates, assumptions about the major Fe-bearing minerals (i.e., oxyhydr(oxides) and silicates) can modulate the total magnitude of $\mathrm{Fe}_{\mathrm{d}}$ deposited to the global oceans by more than $150 \%$.

This is the first study in which the global biogeochemical cycling of mineral-Fe in the atmosphere is explicitly calculated based on acid-base chemistry, organic-promoted mineral dissolution and complexation, $\mathrm{Fe}(\mathrm{II}) / \mathrm{Fe}$ (III) photochemical redox cycling, and accurate dust mineralogy. This complex approach to calculating $\mathrm{Fe}_{\mathrm{d}}$ production in mineral dust is an improvement from past modeling studies, as it more comprehensively captures the processes known to affect $\mathrm{Fe}$ dissolution rates and total concentrations of $\mathrm{Fe}_{\mathrm{d}}$ in mineral dust (i.e., proton- and organic ligand-promoted Fe dissolution, $\mathrm{Fe}(\mathrm{II}) / \mathrm{Fe}(\mathrm{III})$ redox cycling, dissolution rates of differing Fe-containing minerals, and accurate dust particle mineralogy). This allows the model to better represent the existing large spatiotemporal variability in $\mathrm{Fe}_{\mathrm{d}}$ deposition rates, DIF values, and $\mathrm{Fe}(\mathrm{II}) / \mathrm{Fe}(\mathrm{III})$ speciation. Additional chemical equation also allowed the model to capture the potential impact of transition metal ions on atmospheric oxidant (e.g., $\mathrm{HO}_{2}$, OH) levels (e.g., Mao et al., 2013). Furthermore, calculations suggest that for individual dust events $\mathrm{Fe}_{\mathrm{d}}$ fluxes using explicit calculations and prescribed $1 \%$ DIF may differ by more than a factor of 5 . Since marine ecosystem productivity and the associated carbon uptake is often sensitive to episodic $\mathrm{Fe}_{\mathrm{d}}$ fluxes, the next generation earth system models with explicit carbon-climate coupling should consider the implementation of comprehensive modules for dust-Fe biogeochemistry.

\section{Supplementary material related to this article is available online at: http://www.geosci-model-dev.net/6/ 1137/2013/gmd-6-1137-2013-supplement.pdf.}

Acknowledgements. This research was supported by the National Science Foundation through the grant ATM-0826117 and by the National Aeronautics \& Space Administration (NASA) through the grant NNX11AG72G. Matthew Johnson also acknowledges his experience participating in the NASA GEST/JEST summer internship at the Goddard Space Flight Center. The authors would like to thank Daniel Jacob and the Harvard University Atmospheric Chemistry Modeling Group for providing the base model GEOSChem used during our research.

Edited by: S. Arndt

\section{References}

Alexander, B., Savarino, J., Lee, C. C. W., Park, R. J., Jacob, D. J., Thiemens, M. H., Li, Q. B., and Yantosca, R. M.: Sulfate formation in seasalt aerosols: Constraints from oxygen isotopes, J. Geophys. Res., 110, D10307, doi:10.1029/2004JD005659, 2005.

Arimoto, R., Balssam, W., and Schloesslin, C.: Visible spectroscopy of aerosol particles collected on filters: Iron-oxide minerals, Atmos. Environ., 36, 89-96, 2002.

Aumont, O., Maier-Reimer, E., Blain, S., and Monfray, P.: An ecosystem model of the global ocean including $\mathrm{Fe}$, Si, P colimitations, Global Biogeochem. Cy., 17, 1060, doi:10.1029/2001GB001745, 2003.

Balmer, M. E. and Sulzberger, B.: Atrazine degradation in irradiated iron/oxalate systems: Effects of $\mathrm{pH}$ and oxalate, Environ. Sci. Technol., 33, 2418-2424, 1999.

Barbeau, K.: Photochemistry of organic Fe(III) complexing ligands in oceanic systems, Photochem. Photobiol., 82, 1505-1516, 2006.

Benkelberg, H. J. and Warneck, P.: Photodecomposition of iron(III) hydroxo and sulfato complexes in aqueous solutions: Wavelength dependence of $\mathrm{pH}$ and $\mathrm{SO}_{4}^{-}$quantum yields, J. Phys. Chem., 99, 5214-5221, 1995.

Bey, I., Jacob, D. J., Yantosca, R. M., Logan, J. A., Field, B., Fiore, A. M., Li, Q., Liu, H., Mickley, L. J., and Schultz, M.: Global modeling of tropospheric chemistry with assimilated meteorology: Model description and evaluation, J. Geophys. Res., 106 23073-23095, 2001.

Bielski, B. H. J., Cabelli, D. E., Arudi, R. L., and Ross, A. B.: Reactivity of $\mathrm{HO}_{2} / \mathrm{O}_{2}$ radicals in aqueous solution, J. Phys. Chem. Ref. Data, 14, 1041-1100, 1985.

Boyd, P. W., Watson, A. J., Law, C. S., Abraham, E. R., Trull, T., Murdoch, R., Bakker, D. C. E., Bowie, A. R., Buesseler, K. O., Chang, H., Charette, M., Croot, P., Downing, K., Frew, R., Gall, M., Hadfield, M., Hall, J., Harvey, M., Jameson, G., LaRoche, J., Liddicoat, M., Ling, R., Maldonado, M. T., McKay, R. M., Nodder, S., Pickmere, S., Pridmore, R., Rintoul, S., Safi, K., Sutton, P., Strzepek, R., Tanneberger, K., Turner, S., Waite, A., and Zeldis, J.: A mesoscale phytoplankton bloom in the polar Southern Ocean stimulated by iron fertilization, Nature, 407, 695-702, 2000.

Boyd, P. W., Jickells, T., Law, C. S., Blain, S., Boyle, E. A., Buesseler, K. O., Coale, K. H., Cullen, J. J., de Baar, H. J. W., Follows, M., Harvey, M., Lancelot, C., Levasseur, M., Owens, N. P. J., Pollard, R., Rivkin, R. B., Sarmiento, J., Schoemann, V., Smetacek, V., Takeda, S., Tsuda, A., Turner, S., and Watson, A. J.: Mesoscale iron enrichment experiments 1993-2005: Synthesis and future directions, Science, 315, 612-617, 2007.

Brandt, C. and van Eldik, R.: Transition metal-catalyzed oxidation of sulfur(IV) oxides, Atmospheric-relevant processes and mechanisms, Chem. Rev., 95, 119-190, 1995.

Bromley, L. A.: Thermodynamic properties of strong electrolytes in aqueous solution, AIChE J., 19, 313-320, 1973.

Cheah, S.-F., Kraemer, S. M., Cervini-Silva, J., and Sposito, G.: Steady-state dissolution kinetics of goethite in the presence of desferrioxamine B and oxalate ligands: implications for the microbial acquisition of iron, Chemical Geology, 198, 63-75, 2003

Chen, Y.: Sources and fate of atmospheric nutrients over the remote oceans and their role on controlling marine diazotrophic microorganisms, 1-224, University of Maryland Center for Environmen- 
tal Science, 2004.

Chen, Y. and Siefert, R. L.: Determination of various types of labile atmospheric iron over remote oceans, J. Geophys. Res., 108, 4774, doi:10.1029/2003JD003515, 2003.

Chen, Y. and Siefert, R. L.: Seasonal and spatial distributions and dry deposition fluxes of atmospheric total and labile iron over the tropical and subtropical North Atlantic Ocean, J. Geophys. Res., 109, D09305, doi:10.1029/2003JD003958, 2004.

Chin, M., Ginoux, P., Kinne, S., Torres, O., Holben, B., Duncan, B., Martin, R., Logan, J., Higurashi, A., and Nakajima, T.: Tropospheric aerosol optical thickness from the GOCART model and comparisons with satellite and sunphotometer measurements, J. Atmos. Sci., 59, 461-483, 2002.

Coale, K. H., Johnson, K. S., Fitzwater, S. E., Gordon, R. M., Tanner, S., Chavez, F. P., Ferioli, L., Sakamoto, C., Rogers, P., Millero, F., Steinberg, P., Nightingale, P., Cooper, D., Cochlan, W. P., Landry, M. R., Constantinou, J., Rollwagen, G., Trasvina, A., and Kudela, R.: A massive phytoplankton bloom induced by an ecosystem-scale iron fertilization experiment in the equatorial Pacific Ocean, Nature, 383, 495-501, doi:10.1038/383495a0, 1996.

Cornell R. M. and Schindler, P. W.: Photochemical dissolution of goethite in acid/oxalate solution, Clays Clay Miner., 35, 347352, 1987.

Cornell, R. M. and Schwertmann, U.: The iron oxides, structure, properties, reactions, occurrence and uses, John Wiley, Hoboken, NJ, 573 pp., 1996.

Cornell, R. M., Posner, A. M., and Quirk, J. P.: Kinetics and mechanisms of the acid dissolution of Goethite $(\alpha-\mathrm{FeOOH})$, J. Inorg. Nucl. Chem., 38, 563-567, 1976.

Cwiertny, D. M., Hunter, G. J., Pettibone, J. M., Scherer, M. M., and Grassian, V. H.: Surface chemistry and dissolution of $\alpha$ FeOOH nanorods and microrods: Environmental implications of size-dependent interactions with oxalate, J. Phys. Chem., 113, 2175-2186, 2009.

Dedik, A. N. and Hoffmann P.: Chemical characterization of iron in atmospheric aerosols, Atmos. Environ., 26, 2545-2548, 1992.

Deguillaume, L., Leriche, M., Desboeufs, K., Mailhot, G., George, C., and Chaumerliac, N.: Transition metals in atmospheric liquid phases: Sources, reactivity, and sensitivity parameters, Chem. Rev., 105, 3388-3431, 2005.

Dos Santos Afonso, M., Morando, P. J., Blesa, M. A., Banwart, S., and Stumm, W.: The reductive dissolution of iron oxides by ascorbate, J. Colloid Interface Sci., 138, 74-82, 1990.

Duce, R. A. and Tindale, N. W.: Atmospheric transport of iron and its deposition in the ocean, Limnol. Oceanogr., 36, 1715-1726, 1991.

Duckworth, O. W. and Martin, S. T.: Surface complexation and dissolution of hematite by C1-C6 dicarboxylic acids at $\mathrm{pH}=5$, Geochim. Cosmochim. Acta, 65, 4289-4301, 2001.

Epstein, I. R., Kustin, K., and Simoyi, R. H.: Nitrous acid decomposition catalyzed by an iron(II) complex: Tris(3,4,7,8-tetramethyl1,10-phenanthroline)iron(II) ${ }^{1}$, J. Am. Chem. Soc., 104, 712-717, 1982.

Fairlie, T. D., Jacobs, D. J., and Rokjin, R. J.: The impact of transpacific transport of mineral dust in the United States, Atmos. Environ., 41, 1251-1266, 2007.

Falkowski, P. G.: Evolution of the nitrogen cycle and its influence on the biological sequestration of $\mathrm{CO}_{2}$ in the ocean, Nature, 387,
272-275, 1997.

Faust, B. C. and Zepp, R. G.: Photochemistry of aqueous iron(III)polycarboxylate complexes: Roles in the chemistry of atmospheric and surface waters, Environ. Sci. Technol., 27, 25172522, 1993.

Fischer, R. B. and Peters, D. G.: Chemical equilibrium, Saunders Limited, 1970.

Fu, H., Cwiertny, D. M., Carmichael, G. R., Scherer, M. M., and Grassian, V. H.: Photoreductive dissolution of Fe-containing mineral dust particles in acidic media, J. Geophys. Res., 115, D11304, doi:10.1029/2009JD012702, 2010.

Fu, T.-M., Jacob, D. J., Wittrock, F., Burrows, J. P., Vrekoussis, M., and Henze, D. K.: Global budgets of atmospheric glyoxal and methylglyoxal, and implications for formation of secondary organic aerosols, J. Geophys. Res., 113, D15303, doi:10.1029/2007JD009505, 2008.

Fung, I. Y., Meyn, S. K., Tegen, I., Doney, S. C., John, J. G., and Bishop, J. K. B.: Iron supply and demand in the upper ocean, Global Biogeochem. Cy., 14, 281-291, 2000.

Furukawa, T. and Takahashi, Y.: Oxalate metal complexes in aerosol particles: implications for the hygroscopicity of oxalatecontaining particles, Atmos. Chem. Phys., 11, 4289-4301, doi:10.5194/acp-11-4289-2011, 2011.

Getoff, N., Schwoerer, F., Markovic, V. M., and Sehested, K.: Pulse radiolysis of oxalic acid and oxalates, J. Phys. Chem., 75, 749755, 1971.

Ginoux, P., Chin, M., Tegen, I., Prospero, J. M., Holben, B., Dubovik, O., and Lin, S.-J.: Sources and distributions of dust aerosols simulated with the GOCART model, J. Geophys. Res., 106, 20255-20273, 2001.

Gregg, W., Ginoux, P., Schopf, P. S., and Casey, N. W.: Phytoplankton and iron: Validation of a global three-dimensional ocean biogeochemical model, Deep Sea Res. Part II, 50, 3143-3169, 2003.

Heald, C. L., Jacob, D. J., Park, R. J., Alexander, B., Fairlie, T. D., Yantosca, R. M., and Chu, D. A.: Transpacific transport of Asian anthropogenic aerosols and its impact on surface air quality in the United States, J. Geophys. Res., 111, D14310, doi:10.1029/2005JD006847, 2006.

Hoffmann, P., Dedik, A. N., Ensling, J., Weinbruch, S., Weber, S., Sinner, T., Gutlich, P., and Ornter, H. M.: Speciation of iron in atmospheric aerosol samples, J. Aerosol Sci., 27, 325-337, 1996.

Huneeus, N., Schulz, M., Balkanski, Y., Griesfeller, J., Prospero, J., Kinne, S., Bauer, S., Boucher, O., Chin, M., Dentener, F., Diehl, T., Easter, R., Fillmore, D., Ghan, S., Ginoux, P., Grini, A., Horowitz, L., Koch, D., Krol, M. C., Landing, W., Liu, X., Mahowald, N., Miller, R., Morcrette, J.-J., Myhre, G., Penner, J., Perlwitz, J., Stier, P., Takemura, T., and Zender, C. S.: Global dust model intercomparison in AeroCom phase I, Atmos. Chem. Phys., 11, 7781-7816, doi:10.5194/acp-11-7781-2011, 2011.

Ito, A.: Contrasting the effect of iron mobilization on soluble iron deposition to the ocean in the Northern and Southern Hemispheres, J. Meteorol. Soc. Jpn., 90A, 167-188, 2012.

Ito, A. and Feng, Y.: Role of dust alkalinity in acid mobilization of iron, Atmos. Chem. Phys., 10, 9237-9250, doi:10.5194/acp-109237-2010, 2010.

Jacobsen, F., Holcman, J., and Sehested, K.: Reactions of the ferryl ion with some compounds found in cloud water, Int. J. Chem. Kinet., 30, 215-224, 1998. 
Jacobson, M. Z.: Computation of global photochemistry with SMVGEARII, Atmos. Environ., 29, 2541-2546, 1995.

Jacobson, M. Z.: Improvement of SMVGEARII on vector and scalar machines through absolute error tolerance control, Atmos. Environ., 32, 791-796, 1998.

Jacobson, M. Z. and Turco, R. P.: SMVGEAR: A sparse-matrix, vectorized gear code for atmospheric models, Atmos. Environ., 2, 273-284, 1994.

Jayson, G. G., Parson, B. J., and Swallow, A. J.: Oxidation of ferrous ions by perhydroxyl radicals, J. Chem. Soc. Faraday Trans., 69, 236-242, 1973.

Jickells, T. D., An, Z. S., Andersen, K. K., Baker, A. R., Bergametti, G., Brooks, N., Cao, J. J., Boyd, P. W., Duce, R. A., Hunter, K. A., Kawahata, H., Kubilay, N., LaRoche, J., Liss, P. S., Mahowald, N., Prospero, J. M., Ridgwell, A. J., Tegen, I., and Torres, R.: Global iron connections between desert dust, ocean biogeochemistry, and climate, Science, 308, 67-71, 2005.

Johansen, A. M., Siefert, R. L., and Hoffmann, M. R.: Chemical composition of aerosols collected over the tropical North Atlantic Ocean, J. Geophys. Res., 105, 15277-15312, 2000.

Johnson, M. S., Meskhidze, N., Solmon, F., Gassó, S., Chuang, P. Y., Gaiero, D. M., Yantosca, R. M., Wu, S., Wang, Y., and Carouge, C.: Modeling dust and soluble iron deposition to the South Atlantic Ocean, J. Geophys. Res., 115, D15202, doi:10.1029/2009JD013311, 2010.

Johnson, M. S., Meskhidze, N., Kiliyanpilakkil, V. P., and Gassó, S.: Understanding the transport of Patagonian dust and its influence on marine biological activity in the South Atlantic Ocean, Atmos. Chem. Phys., 11, 2487-2502, doi:10.5194/acp-11-24872011, 2011.

Johnson, M. S., Meskhidze, N., and Kiliyanpilakkil, V. P.: A global comparison of GEOS-Chem-predicted and remotely-sensed mineral dust aerosol optical depth and extinction profiles, J. Adv. Model. Earth Syst., 4, M07001, doi:10.1029/2011MS000109, 2012

Journet, E., Desboeufs, K. V., Caquineau, S., and Colin, J.-L.: Mineralogy as a critical factor of dust iron solubility, Geophys. Res. Lett., 35, L07805, doi:10.1029/2007GL031589, 2008.

Kawamura, K. and Ikushima, K.: Seasonal changes in the distribution of dicarboxylic acids in the urban atmosphere, Environ. Sci. Technol., 27, 2227-2235, 1993.

Kawamura, K., Kasukabe, H., and Barrie, L. A.: Source and reaction pathways of dicarboxylic acids, ketoacids and dicarbonyls in arctic aerosols at polar sunrise, Atmos. Environ., 30, 1709-1722, doi:10.1016/1352-2310(95)00395-9, 1996.

Kawamura, K., Imai, Y., and Barrie, L. A.: Photochemical production and loss of organic acids in high Arctic aerosols during long range transport and polar sunrise ozone depletion events, Atmos. Environ., 39, 599-614, doi:10.1016/j.atmosenv.2004.10.020, 2005.

Kieber, R. J., Skrabal, S. A., Smith, B. J., and Willey, J. D.: Organic complexation of $\mathrm{Fe}$ (II) and its impact on the redox cycling of iron in rain, Environ. Sci. Technol., 39, 1576-1583, 2005.

Kleindienst, T. E., Smith, D. F., Li, W., Edney, E. O., Driscoll, D. J., Speer, R. E., and Weathers, W. S.: Secondary organic aerosol formation from the oxidation of aromatic hydrocarbons in the presence of dry submicron ammonium sulfate aerosol, Atmos. Environ., 33, 3669-3681, 1999.
Kraemer, S. M., Butler, A., Borer, P. M., and Cervini-Silva, J.: Siderophores and the dissolution of iron-bearing minerals in marine systems, in: Reviews in Mineralogy and Geochemistry, edited by: Banfield, J. F., Cervini-Silva, J., and Nealson, K. M., Mineralogical Society of America, Washington, DC, 53-84, 2005.

Kremer, M. L.: The Fenton reaction, Dependence of the rate on $\mathrm{pH}$, J. Phys. Chem. A, 107, 1734-1741, 2003.

Kusik, C. L. and Meissner, H. P.: Electrolyte activity coefficients in inorganic processing, AIChE Symp. Ser., 173, 14-20, 1978.

Legrand, M., Preunkert, S., Oliveira, T., Pio, C., Hammer, S., Gelencser, A., Kasper-Giebl, A., and Laj, P.: Origin of $\mathrm{C}_{2}-\mathrm{C}_{5}$ dicarboxylic acids in the European atmosphere inferred from year round aerosol study conducted at a west-east transect, J. Geophys. Res., 112, D23S07, doi:10.1029/2006JD008019, 2007.

Liu, H., Jacob, D. J., Bey, I., and Yantosca, R. M.: Constraints from $210 \mathrm{~Pb}$ and $7 \mathrm{Be}$ on wet deposition and transport in a global threedimensional chemical tracer model driven by assimilated meteorological fields, J. Geophys. Res., 106, 12109-12128, 2001.

Logager, T., Holcman, J., Sehested, K., and Pedersen, T.: Oxidation of ferrous ions by ozone in acidic solution, Inorg. Chem., 31, 3523-3529, 1992.

Luo, C. and Gao, Y.: Aeolian iron mobilisation by dust-acid interactions and their implications for soluble iron deposition to the ocean: a test involving potential anthropogenic organic acidic species, Environ. Chem., 7, 153-161, doi:10.1071/EN09116, 2010.

Luo, C., Mahowald, N. M., Meskhidze, N., Chen, Y., Siefert, R. L., Baker, A. R., and Johansen, A. M.: Estimation of iron solubility from observations and a global aerosol model, J. Geophys. Res., 110, D23307, doi:10.1029/2005JD006059, 2005.

Luo, C., Mahowald, N., Bond, T., Chuang, P. Y., Artaxo, P., Siefert, R., Chen, Y., and Schauer, J.: Combustion iron distribution and deposition, Global Biogeochem. Cy., 22, GB1012, doi:10.1029/2007GB002964, 2008.

Mahowald, N. M., Engelstaedter, S., Luo, C., Sealy, A., Artaxo, P., Benitez-Nelson, C., Bonnet, S., Chen, Y., Chuang, P. Y., Cohen, D. D., Dulac, F., Herut, B., Johansen, A. M., Kubilay, N., Losno, R., Maenhaut, W., Paytan, A., Prospero, J. A., Shank, L. M., and Siefert, R. L.: Atmospheric iron deposition: Global distribution, variability, and human perturbations, Annu. Rev. Mar. Sci., 1, 245-278, 2009.

Mao, J., Fan, S., Jacob, D. J., and Travis, K. R.: Radical loss in the atmosphere from $\mathrm{Cu}-\mathrm{Fe}$ redox coupling in aerosols, Atmos. Chem. Phys., 13, 509-519, doi:10.5194/acp-13-509-2013, 2013.

Martin, J. H.: Glacial-interglacial $\mathrm{CO}_{2}$ change: The Iron Hypothesis, Paleoceanography, 5, 1-13 1990.

Martin, J. H. and Fitzwater, S. E.: Iron-deficiency limits phytoplankton growth in the northeast pacific subarctic, Nature, 331, 341$343,1988$.

Meskhidze, N., Chameides, W. L., Nenes, A., and Chen, G.: Iron mobilization in mineral dust: Can anthropogenic $\mathrm{SO}_{2}$ emissions affect ocean productivity?, Geophys. Res. Lett., 30, 2085, doi:10.1029/2003GL018035, 2003.

Meskhidze, N., Chameides, W. L., and Nenes, A.: Dust and pollution: A recipe for enhanced ocean fertilization?, J. Geophys Res., 110, D03301, doi:10.1029/2004JD005082, 2005.

Meyerstein, D.: Trivalent copper: I: a pulse radiolytic study of the properties of the aquocomplex, Inorg. Chem., 10, 638-641, 1971. 
Millero, F. J., Sotolongo, S., and Izaguirre, M.: The kinetics of oxidation of Fe(II) in seawater, Geochim. Cosmochim. Acta, 51, 793-801, 1987.

Mills, M. M., Ridame, C., Davey, M., La Roche, J., and Geider, R. J.: Iron and phosphorus co-limit nitrogen fixation in the eastern tropical north Atlantic, Nature, 429, 292-294, 2004.

Moore, J. K., Doney, S. C., and Lindsay, K.: Upper ocean ecosystem dynamics and iron cycling in a global threedimensional model, Global Biogeochem. Cy., 18, GB4028, doi:10.1029/2004GB002220, 2004.

Myriokefalitakis, S., Vrekoussis, M., Tsigaridis, K., Wittrock, F., Richter, A., Brühl, C., Volkamer, R., Burrows, J. P., and Kanakidou, M.: The influence of natural and anthropogenic secondary sources on the glyoxal global distribution, Atmos. Chem. Phys., 8, 4965-4981, doi:10.5194/acp-8-4965-2008, 2008.

Myriokefalitakis, S., Tsigaridis, K., Mihalopoulos, N., Sciare, J., Nenes, A., Kawamura, K., Segers, A., and Kanakidou, M.: In-cloud oxalate formation in the global troposphere: a 3-D modeling study, Atmos. Chem. Phys., 11, 5761-5782, doi:10.5194/acp-11-5761-2011, 2011.

Nenes, A., Pandis, S. N., and Pilinis, C.: ISORROPIA: A new thermodynamic equilibrium model for multiphase multicomponent inorganic aerosols, Aquat. Geochem., 4, 123-152, 1998.

Nickovic, S., Vukovic, A., Vujadinovic, M., Djurdjevic, V., and Pejanovic, G.: Technical Note: High-resolution mineralogical database of dust-productive soils for atmospheric dust modeling, Atmos. Chem. Phys., 12, 845-855, doi:10.5194/acp-12-8452012, 2012.

Nickovic, S., Vukovic, A., and Vujadinovic, M.: Atmospheric processing of iron carried by mineral dust, Atmos. Chem. Phys. Discuss., 13, 2695-2723, doi:10.5194/acpd-13-2695-2013, 2013.

Okin, G. S., Baker, A. R., Tegen, I., Mahowald, N. M., Dentener, F. J., Duce, R. A., Galloway, J. N., Hunter, K., Kanakidou, M., Kubilay, N., Prospero, J. M., Sarin, M., Surapipith, V., Uematsu, M., and Zhu, T.: Impacts of atmospheric nutrient deposition on marine productivity: Roles of nitrogen, phosphorus, and iron, Global Biogeochem. Cy., 25, GB2022, doi:10.1029/2010GB003858, 2011.

Olsen, J., Prather, M., Berntsen, T., Carmichael, G., Chatfield, R., Connell, P., Derwent, R., Horowitz, L., Jin, S., Kanakidou, M., Kasibhatla, P., Kotamarthi, R., Kuhn, M., Law, K., Penner, J., Perliski, L., Sillman, S., Stordal, F., Thompson, A., and Wild, O.: Results from the Intergovernmental Panel on Climate Change photochemical model intercomparison (PhotoComp), J. Geophys. Res., 102, 5979-5991, 1997.

Paris, R., Desboeufs, K. V., and Journet, E.: Variability of dust iron solubility in atmospheric waters: Investigation of the role of oxalate organic complexation, Atmos. Environ., 45, 6510-6517, 2011.

Park, R. J., Jacob, D. J., Field, B. D., Yantosca, R. M., and Chin, M.: Natural and transboundary pollution influences on sulfate nitrateammonium aerosols in the United States: Implications for policy, J. Geophys. Res., 109, D15204, doi:10.1029/2003JD004473, 2004.

Pehkonen, S. O., Siefert, R., Erel, Y., Webb, S., and Hoffmann, M. R.: Photoreduction of iron oxyhydroxides in the presence of important atmospheric organic compounds, Environ. Sci. Technol., 27, 2056-2062, 1993.
Peterson, T. D., Whitney, F. A., and Harrison, P. J.: Macronutrient dynamics in an anticyclonic mesoscale eddy in the Gulf of Alaska, Deep-Sea Res. II, 52, 909-932, 2005.

Pikaev, A. K., Sibirskaya, G. K., Shirshov, E. M., Glazunov, P. Y., and Spitsyn, V. I.: Pulsed radiolysis of concentrated aqueous solutions of nitric acid, Dokl. Phys. Chem., Proc. Acad. Sci. USSR, 215, 328-331, 1974.

Prospero, J. M., Ginoux, P., Torres, O., and Nicholson, S. E.: Environmental characterization of global sources of atmospheric soil dust identified with the Nimbus 7 Total Ozone Mapping Spectrometer (TOMS) absorbing aerosol product, Rev. Geophys., 40, 1002, doi:10.1029/2000RG000095, 2002.

Raabe, G.: Eine laserphotolytische studie zur kinetik der reaktionen des $\mathrm{NO}_{3}^{-}$radikals in wäßriger lösung, Cuvillier, Göttingen, Germany, 1996.

Raiswell, R. and Canfield, D. E.: The iron biogeochemical cycle past and present, Geochem. Perspect., 1, 1-220, 2012.

Rinaldi, M., Decesari, S., Carbone, C., Finessi, E., Fuzzi, S., Ceburnis, D., O’Dowd, C. D., Sciare, J., Burrows, J. P., Vrekoussis, M., Ervens, B., Tsigaridis, K., and Facchini, M. C.: Evidence of a natural marine source of oxalic acid and a possible link to glyoxal, J. Geophys. Res., 116, D16204, doi:10.1029/2011JD015659, 2011.

Roy, E. G., Wells, M. L., and King, D. W.: Persistence of iron(II) in surface waters of the western subarctic Pacific, Limnol. Oceanogr., 53, 89-98, 2008.

Rubin, M., Berman-Frank, I., and Shaked, Y.: Dust and mineral iron utilization by the marine diazotroph Trichodesmium, Nat. Geosci., 4, 529-534, 2011.

Rush, J. D. and Bielski, B. H. J.: Pulse radiolytic studies of the reactions of $\mathrm{HO}_{2} / \mathrm{O}_{2}$ with $\mathrm{Fe}(\mathrm{II}) / \mathrm{Fe}$ (III) ions, The reactivity of $\mathrm{HO}_{2} / \mathrm{O}_{2}$ with ferric ions and its implication on the occurrence of the Haber-Weiss reaction, J. Phys. Chem., 89, 5062-5066, doi:10.1021/j100269a035, 1985.

Samson, S. D. and Eggleston, C. M.: Nonsteady-state dissolution of goethite and hematite in response to $\mathrm{pH}$ jumps: the role of adsorbed Fe(III), Water-Rock Interactions, Ore Deposits, and Environmental Geochemistry, edited by: Hellman, R. and Wood, S. A., 2002.

Santana-Casiano, J. M., Gonzalez-Davila, M., and Millero, F. J.: Oxidation of nanomolar levels of Fe(II) with oxygen in natural waters, Environ. Sci. Technol., 39, 2073-2079, 2005.

Sciare, J., Favez, O., Sarda-Esteve, R., Oikonomou, K., Cachier, H., and Kazan, V.: Long-term observations of carbonaceous aerosols in the Austral Ocean atmosphere: Evidence of a biogenic marine organic source, J. Geophys. Res., 114, D15302, doi:10.1029/2009JD011998, 2009.

Schwertmann, U.: Solubility and dissolution of iron oxides, Plant Soil, 130, 1-25, 1991.

Sedlak, D. L. and Hoigné, J.: The role of copper and oxalate in the redox cycling of iron in atmospheric waters, Atmos. Environ., 27A, 2173-2185, 1993.

Sedwick, P. N., Sholkovitz, E. R., and Church, T. M.: Impact of anthropogenic combustion emissions on the fractional solubility of aerosol iron: Evidence from the Sargasso Sea, Geochem. Geophys. Geosyst., 8, Q10Q06, doi:10.1029/2007GC001586, 2007.

Seinfeld, J. H. and Pandis, S. N.: Atmospheric Chemistry and Physics: From Air Pollution to Climate Change, Wiley, New York, 1998. 
Shi, Z., Krom, M. D., Jickells, T. D., Bonneville, S., Carslaw, K. S., Mihalopoulos, N., Baker, A. R., and Benning, L. G.: Impacts on iron solubility in the mineral dust by processes in the source region and the atmosphere: A review, Aeolian Research, 5, 2142, 2012.

Sholkovitz, E. R., Sedwick, P. N., Church, T. M., Baker, A. R., and Powell, C. F.: Fractional solubility of aerosol iron: Synthesis of a global-scale data set, Geochim. Cosmochim. Acta, 89, 173-189, 2012.

Sidhu, P. S., Gilkes, R. J., Cornell, R. M., Posner, A. M., and Quirk, J. P.: Dissolution of iron oxides and oxyhydroxides in hydrochloric and perchloric acids, Clays Clay Minerals, 29, 269276, 1981.

Siefert, R. L., Johansen, A. M., Hoffmann, M. R., and Pehkonen, S. O.: Measurements of trace metal $(\mathrm{Fe}, \mathrm{Cu}, \mathrm{Mn}, \mathrm{Cr})$ oxidation states in fog and stratus clouds, J. Air Waste Manage., 48, 128143, 1998.

Sinreich, R., Coburn, S., Dix, B., and Volkamer, R.: Ship-based detection of glyoxal over the remote tropical Pacific Ocean, Atmos. Chem. Phys., 10, 11359-11371, doi:10.5194/acp-1011359-2010, 2010.

Solmon, F., Chuang, P. Y., Meskhidze, N., and Chen, Y.: Acidic processing of mineral dust iron by anthropogenic compounds over the north Pacific Ocean, J. Geophys. Res., 114, D02305, doi:10.1029/2008JD010417, 2009.

Spokes, L. J., Jickells, T. D., and Lim, B.: Solubilization of aerosol trace metals by cloud processing: A laboratory study, Geochim. Cosmochim. Acta, 58, 3281-3287, 1994.

Stumm, W. and Morgan, J. J. (Eds.): Aquatic Chemistry: An Introduction Emphasizing Chemical Equilibria in Natural Waters, John Wiley, Hoboken, N. J., 780 pp., 1981.

Stumm, W., Furrer, G., Wieland, E., and Zinder, B.: The effects of complex-forming ligands on the dissolution of oxides and aluminosilicates, in: The Chemistry of Weathering, edited by: Drever, J. I., Dordrecht, D. Reidel Publishing Co, 55-74, 1985.

Sullivan, R. C., Moore, M. J. K., Petters, M. D., Kreidenweis, S. M., Roberts, G. C., and Prather, K. A.: Effect of chemical mixing state on the hygroscopicity and cloud nucleation properties of calcium mineral dust particles, Atmos. Chem. Phys., 9, 33033316, doi:10.5194/acp-9-3303-2009, 2009.

Suter, D., Banwart, S., and Stumm, W.: Dissolution of hydrous iron(III) oxides by reductive mechanisms, Langmuir, 7, 809-813, 1991.

Taylor, S. R. and McLennan, S. M.: The Continental Crust: its Composition and Evolution, Blackwell Scientific, Oxford, England, 1985.
Trapp, J. M., Millero, F. J., and Prospero, J. M.: Trends in the solubility of iron in dust-dominated aerosols in the equatorial Atlantic trade winds: Importance of iron speciation and sources, Geochem. Geophys. Geosyst., 11, Q03014, doi:10.1029/2009GC002651, 2010.

Volkamer, R., Coburn, S. C., Dix, B. K., and Sinreich, R.: The Eastern Pacific Ocean is a source for short lived atmospheric gases: glyoxal and iodine oxide, CLIVAR Exchanges, 15, 30-33, 2010.

Waite, T. D., Torikov, A., and Smith, J. D.: Photoassisted dissolution of colloidal iron oxides by thiol containing compounds. I. Dissolution of hematite $\left(\alpha-\mathrm{Fe}_{2} \mathrm{O}_{3}\right)$, J. Colloid Interface Sci., 112, 412-420, 1986.

Wiederhold, J. G., Kraemer, S. M., Teutsch, N., Borer, P. M., Halliday, A. N., and Kretzschmar, R.: Iron isotope fractionation during proton-promoted, ligand-controlled, and reductive dissolution of goethite, Environ. Sci. Technol., 40, 3787-3793, doi:10.1021/es052228y, 2006.

Wild, O., Zhu, Q., and Prather, M. J.: Fast-J: Accurate simulation of in- and below-cloud photolysis in global chemical models, J. Atmos. Chem., 37, 245-282, 2000.

$\mathrm{Xu}, \mathrm{N}$. and Gao, Y.: Characterization of hematite dissolution affected by oxalate coating, kinetics and pH, Appl. Geochem., 23, 783-793, 2008.

Yu, J., Huang, X., Xu, J., and Hu, M.: When aerosol sulfate goes up, so does oxalate: implication for the formation mechanisms of oxalate, Environ. Sci. Technol., 39, 128-133, 2005.

Zender, C. S., Newman, D., and Torres, O.: Spatial heterogeneity in aeolian erodibility: Uniform, topographic, geomorphic, and hydrologic hypotheses, J. Geophys. Res., 108, doi:10.1029/2002JD003039, 2003.

Zhang, L., Gong, S. L., Padro, J., and Barrie, L.: A size-segregated particle dry deposition scheme for an atmospheric aerosol module, Atmos. Environ., 35, 549-560, 2001.

Zhu, X. R., Prospero, J. M., and Millero, F. J.: Diel variability of soluble Fe(II) and soluble total Fe in North African dust in the trade winds at Barbados, J. Geophys. Res., 102, 21297-21305, 1997.

Zhuang, G., Yi, Z., Duce, R. A., and Brown, P. R.: Link between iron and sulphur cycles suggested by detection of $\mathrm{Fe}$ (II) in remote marine aerosols, Nature, 355, 537-539, 1992.

Ziajka, J., Beer, F., and Warneck, P.: Iron-catalysed oxidation of bisulphite aqueous solution: Evidence for a free radical chain mechanism, Atmos. Environ., 28, 2549-2552, 1994.

Zuo, Y. and Holgné, J.: Formation of hydrogen peroxide and depletion of oxalic acid in atmospheric water by photolysis of iron(III)-oxalato complexes, Environ. Sci. Technol., 26, 1014$1022,1992$. 